$11-2011$

\title{
Voluntary Corporate Environmental Initiatives and Shareholder Wealth
}

Karen Fisher-Vanden

Karin S. Thorburn

Follow this and additional works at: https://repository.upenn.edu/fnce_papers

Part of the Corporate Finance Commons, Environmental Policy Commons, Environmental Studies Commons, and the Finance and Financial Management Commons

\section{Recommended Citation}

Fisher-Vanden, K., \& Thorburn, K. S. (2011). Voluntary Corporate Environmental Initiatives and Shareholder Wealth. Journal of Environmental Economics and Management, 62 (3), 430-445. http://dx.doi.org/

10.1016/j.jeem.2011.04.003

Author Karin S.Thorburn is a full time faculty member of Norwegian School of Economics. She is a visiting professor in the Finance Department of the Wharton School at the University of Pennsylvania.

This paper is posted at ScholarlyCommons. https://repository.upenn.edu/fnce_papers/203

For more information, please contact repository@pobox.upenn.edu. 


\title{
Voluntary Corporate Environmental Initiatives and Shareholder Wealth
}

\author{
Abstract \\ Researchers debate whether environmental investments reduce firm value or actually improve financial \\ performance. We provide some compelling evidence on shareholder wealth effects of membership in \\ voluntary environmental programs (VEPs). Companies announcing membership in EPA's Climate Leaders, \\ a program targeting reductions in greenhouse gas emissions, experience significantly negative abnormal \\ stock returns. The price decline is larger in firms with poor corporate governance structures, and for high \\ market-to-book (i.e., high growth) firms. However, firms joining Ceres, a program involving more general \\ environmental commitments, have insignificant announcement returns, as do portfolios of industry rivals. \\ Overall, corporate commitments to reduce greenhouse gas emissions appear to conflict with firm value \\ maximization. This has important implications for policies that rely on voluntary initiatives to address \\ climate change. Further, we find that firms facing climate-related shareholder resolutions or firms with \\ weak corporate governance standards - giving managers the discretion to make such voluntary \\ environmentally responsible investment decisions - are more likely to join Climate Leaders; decisions \\ that may result in lower firm value.
}

\section{Keywords}

corporate social responsibility, environmentally responsible investing, climate change, greenhouse gas emissions, capital expenditures, shareholder wealth

\section{Disciplines}

Corporate Finance | Environmental Policy | Environmental Studies | Finance and Financial Management

\section{Comments}

Author Karin S. Thorburn is a full time faculty member of Norwegian School of Economics. She is a visiting professor in the Finance Department of the Wharton School at the University of Pennsylvania. 


\title{
Voluntary Corporate Environmental Initiatives and Shareholder Wealth ${ }^{*}$
}

\author{
Karen Fisher-Vanden** \\ Pennsylvania State University \\ Karin S. Thorburn \\ Norwegian School of Economics and Business Administration (NHH)
}

June 14, 2010

\footnotetext{
* We are grateful for helpful comments from Tom Berglund and Espen Eckbo, as well as seminar participants at BI, Harvard's Kennedy School, HKUST, IMD, NHH, the Rockefeller Center and the Tuck School at Dartmouth, Texas A\&M, the universities of Amsterdam and Stavanger, and the SNEE 2009 annual conference. We thank Jonathan Choi, Hanna Breetz, Abe Holland, and Chetan Mehta for research assistance. This research was supported by the Rockefeller Center and the Lindenauer Center for Corporate Governance at the Tuck School of Business, both at Dartmouth College.

**Corresponding author: Department of Agricultural Economics and Rural Sociology, Pennsylvania State University, 112-E Armsby Building, University Park, PA 16870; phone: 814-867-2752; fax: 814-865-3746; email: fishervanden@psu.edu.
} 


\title{
Voluntary Corporate Environmental Initiatives and Shareholder Wealth
}

\begin{abstract}
Researchers debate whether environmental investments reduce firm value or actually improve financial performance. We provide some compelling evidence on shareholder wealth effects of membership in voluntary environmental programs (VEPs). Companies announcing membership in EPA's Climate Leaders, a program targeting reductions in greenhouse gas emissions, experience significantly negative abnormal stock returns. The price decline is larger in firms with poor corporate governance structures, and for high market-to-book (i.e., high growth) firms. However, firms joining Ceres, a program involving more general environmental commitments, have insignificant announcement returns, as do portfolios of industry rivals. Overall, corporate commitments to reduce greenhouse gas emissions appear to conflict with firm value-maximization. This has important implications for policies that rely on voluntary initiatives to address climate change. Further, we find that firms tend to join Climate Leaders either in response to climate-related shareholder resolutions or due to weak corporate governance standards which give managers the discretion to make such voluntary environmentally responsible investment decisionsdecisions that may result in lower firm value.
\end{abstract}

JEL classification: Q5, G31, G38

Keywords: Corporate social responsibility; Environmentally responsible investing; Climate change; Greenhouse gas emissions; Capital expenditures; Shareholder wealth. 


\section{Introduction}

A rapidly growing corporate trend in recent years, that has many taking notice, is the number of companies engaged in voluntary environmentally responsible (VER) activities. These activities span a wide range, including membership in public voluntary programs that encourage pollution reductions, unilateral efforts by companies to improve their environmental performance, and the voluntary public disclosure of environmental performance measures (Khanna, 2001). With this trend, a growing number of people are asking whether better environmental performance translates into higher financial performance. Corporate investments in environmental technologies have traditionally been considered a drain on a firm's resources, creating an inherent conflict between environmental and financial performance (e.g. Palmer et al, 1995; Walley and Whitehead, 1994). However, others have argued that corporate environmental responsibility can actually improve financial performance. Potential gains from improved environmental performance can result from a differentiation of product (increasing customer demand and hence sales and/or margins) by signaling that the company is "green", a reduction in the risk of future environmental liabilities and lawsuits, and a cut in production costs as a result of pollution-reducing measures (Porter and van der Linde, 1995; Reinhardt, 1999). Moreover, improving environmental performance could spur governmental regulatory actions, giving the first-mover firms a competitive advantage once their industry rivals are forced to comply (Reinhardt, 1999).

The empirical evidence on the relationship between environmental performance and financial performance has been mixed. Several approaches have been used to study this relationship: (1) regression analysis; (2) portfolio analysis; and (3) event studies. Regression studies have focused on the relationship between environmental performance and accounting 
profitability measures, with several of these studies documenting a positive relationship. ${ }^{1}$ However, other regression studies—e.g., Jaggi and Freedman (1992), Molloy, Erekson, and Gorman (2002), and Clarkson and Li (2004)—report a mixed or negative relationship between environmental performance measures and accounting profitability. Although a clear explanation for these contrasting results is not obvious, in general it seems that studies where the environmental performance measure is tied to liability, compliance, and regulatory risks find a positive relationship between environmental performance and financial performance. This is consistent with the findings of Khanna and Damon (1999), Anton et al (2004), Darnall et al (2008) and Brouhle et al (2009) which show that liability and regulatory threats are a major motivation for firms joining voluntary programs like EPA's 33/50 Program to reduce toxic emissions and adopting environmental management systems (EMS). Additionally, Malloy, Erekson and Gorman (2002), in their study of investor perceptions, find that environmental investments are interpreted by investors to raise costs (rather than lower them), except in the case where the firm would face non-compliance penalties if these investments were not made. This would imply that firms should experience a negative impact on financial performance from environmental investments unless these investments are made in response to liability, compliance, or regulatory threats—a finding consistent with the empirical evidence.

Portfolio analysis studies have reported similar results. White (1996) and Geczy et al (2005) find that socially or environmentally responsible mutual funds earn lower risk-adjusted returns. Ziegler et al (2009) find that an investment strategy that buys stocks of firms that are making efforts to lower their greenhouse gas emissions and sells stocks of firms with little or no

\footnotetext{
${ }^{1}$ Cormier, Magnan and Morard (1993), Hart and Ahuja (1996), Russo and Fouts (1997), King and Lenox (2001), Konar and Cohen (2001), Guenster et al (2006), and Ziegler et al (2007). Although Telle (2006) finds a positive effect with a pooled regression controlling for industry and size, the author finds that this effect goes away when firm fixed effects are included.
} 
climate change mitigation effort results in a negative abnormal return. However, Cohen, Fenn, and Konar (1997) and Derwall et al (2005) both find that portfolios containing stocks of companies with high environmental performance scores have positive returns and, in the case of Derwall et al (2005), even outperform portfolios containing low environmental performing company stocks. To understand these contrasting results, it is important to examine the environmental performance measure being used in each of these studies. In Cohen, Fenn, and Konar (1997), the environmental performance score is based on Toxic Release Inventory (TRI) data and is a function of the probability of noncompliance detection, expected size of sanctions, and expected reputational loss—all factors that would result in lower firm value. In Derwall et al (2005), the environmental performance ranking is based on Innovest rankings and is a function of historical liabilities, operating risk, eco-efficiency risk, managerial risk, and environmentallyrelated strategic business opportunities, many of which would result in lower firm value. These findings are also consistent with the prediction that firms engaged in environmental activities to lower risk will experience positive returns whereas firms engaged in these activities for other reasons will not.

The results from event studies are also consistent with this prediction. Hamilton (1995), an event study based on TRI data releases, finds that after these data are made publicly available, firms highlighted in the press_-due to their high toxic release numbers-earn significant negative abnormal returns. Thus, investors are interpreting this new information as an increase in the firm's liability or compliance risk that is likely to result in increased costs. Klassen and McLaughlin (1996) find that environmental performance award announcements result in positive abnormal returns while environmental crisis announcements result in negative abnormal returns, also consistent with the prediction that investors will reward information that suggests a future 
increase in firm value and punish information that suggests a decline in firm value. Cañon-deFrancia and Garcés-Ayerbe (2009), in their event study of ISO 14001 certification announcements, find that less polluting and less internationalized firms experience a drop in stock price after their ISO 14001 announcement. The authors interpret this as investors perceiving the resources required to comply with ISO 14001 certification to be costly to the firm with little or no offsetting benefit.

The pervasive use of environmental liability and toxic release data in many of these previous studies reporting a positive relationship between environmental and financial performance, however, limit our ability to generalize these result to investments unrelated to liability, compliance, and regulatory risks. Voluntary environmental programs related to climate change, for instance, originate from a starkly different regulatory context: most greenhouse gases (GHG) are currently not regulated by the U.S. Environmental Protection Agency (EPA) although a number of regional climate initiatives (e.g., the Western Climate Initiative, the Regional Greenhouse Gas Initiative, and the Midwest Greenhouse Gas Reduction Accord) have recently been established, many of which only target the electric power sector and large industrial sources. As a result, liability, compliance, and regulatory risks related to climate are not so clear. How do investors interpret climate-related environmental investments? As a cost to the firm with no offsetting benefit similar to the findings of Cañon-de-Francia and Garcés-Ayerbe (2009)? Or, will investors perceive these investments as adding firm value or avoiding future costs to the firm similar to Russo and Fouts (1997) and King and Lenox (2001)? As emphasized in King and Lenox (2001), the appropriate question may not be, “does it pay to be green?” but rather “when does it pay to be green?” 
In this study we estimate the cumulative abnormal stock returns $(\widehat{C A R})$ for a sample of firms announcing their participation in one of two voluntary environmental programs (VEPs): the EPA's Climate Leaders (CL) program and Ceres. We find that firms announcing membership in Climate Leaders experience a significant drop in stock price (on average $-1.0 \%$ ). Moreover, when firms as part of the CL program subsequently announce a specific goal for the reduction of their GHG gas emissions, their stock price declines further (-1.1\% on average). Thus, it seems that investors are interpreting membership in Climate Leaders and subsequent pledges to reduce greenhouse gas emissions as imposing significant costs on the firm, leading to a decline in shareholder wealth. The firms joining Ceres, however, have insignificant announcement $\overline{C A R}$, likely due to the program's broad scope and general principles (rather than specific standards) in all environmental areas (not just climate change), making it difficult for investors to assess what membership implies for the firm's cost structure. The announcement returns are more negative for firms with governance structures that imply fewer shareholder rights. That is, the marginal effect on firm value is more dramatic when shareholders have less influence on the firm's activities. Moreover, the stock price drop is greater for firms with high market-to-book ratios, suggesting that climate investments are interpreted by investors to be more costly for high growth firms.

We also analyze the valuation effect on the industry competitors of the sample firms. Industry rivals of firms joining Climate Leaders or Ceres could be negatively affected by these firms announcing their membership in these programs for a number of reasons. First, the sample firms could gain competitive advantage as first-movers in complying with expected future regulation. Second, as discussed in Reinhardt (1999), these firm may be attempting to "manage their competitors” by engaging in environmentally responsible activities that would encourage 
regulation that could benefit these firms in particular. Thus, if the announcement spurs federal regulation of greenhouse gas emissions that will ultimate change the cost structure of the industry we expect a negative rival stock price reaction. Alternatively, rival firms could benefit positively from the sample firms' decision to join CL or Ceres. For example, investors could decide to dump shares of the CL firms and invest in non-CL firms, which would result in a positive return for rival firms if these purchases are anticipated (or executed) at the time of announcement and span across a sufficient number of rivals. We find, however, insignificant announcement returns for portfolios of industry rival stocks. This is consistent with the notion that the average membership in Climate Leaders or Ceres does not materially affect the cost structure of the industry. It is possible that the sample firms' environmental capital expenditures are limited by industry competitive pressures, thus reducing the competitive advantage of the firm should regulation eventually force rivals to make comparable investments.

Our event study results suggest that investors are interpreting participation in Climate Leaders as imposing a significant cost on the firm. If this is the case, and given that the board of directors has a fiduciary duty to shareholders, why are firms joining Climate Leaders? A number of studies have attempted to identify key motivating factors for a company's involvement in voluntary environmental activities. ${ }^{2}$ Khanna and Damon (1999), Anton, Deltas, and Khanna (2004), and Brouhle, Griffiths, and Wolverton (2009) each find liability and regulatory threats to be key motivating factors for voluntary environmental activities, suggesting that these voluntary programs are not likely to be effective without the threat of mandatory regulation. Anton, Deltas, and Khanna (2004) also find that pressure from consumers and investors is motivating firms to adopt environmental management systems (EMS).

\footnotetext{
${ }^{2}$ See Khanna (2001) for a nice survey.
} 
To assess the importance of institutional pressure, Reid and Toffel (2009) test whether pressure from shareholder activists and a firm's location increase the probability that the firm voluntarily discloses its emissions of carbon as part of the Carbon Disclosure Project, a nonprofit organization that maintains a database of self-reported company carbon emissions. They find that shareholder resolutions on climate change increase the probability of disclosure, and firms located in states with regional climate initiatives are more likely to disclose emissions. Their study, however, does not assess whether this disclosure has an impact on the firm's stock price. Darnall, Henriques, and Sadorsky (2008) and Cañon-de-Francia and Garcés-Ayerbe (2009), however, find that firms adopting environmental management systems in response to these types of institutional pressures do not experience positive financial returns for their efforts, as they may be purely symbolic and therefore not implemented efficiently. Cañon-de-Francia and Garcés-Ayerbe (2009) distinguish between reactive and proactive environmental efforts, and find that reactive efforts—i.e., efforts undertaken in reaction to institutional pressures—are more likely to result in negative returns whereas proactive efforts are more likely to result in positive returns.

To understand why firms join the Climate Leaders program, we extend our analysis to include a cross-sectional probit analysis that attempts to identify factors that could explain why firms join, limiting our analysis to the industries represented by the sample firms. We find that the likelihood that a firm will join the Climate Leaders program increases the more hostile the firm's corporate governance structure is to shareholders and the better the firm's past environmental record. Importantly, controlling for corporate governance structure, we find that firms with a greater number of climate-related shareholder resolutions are much more likely to join Climate Leaders, similar to the findings of Reid and Toffel (2009). The negative 
announcement returns coupled with the significantly positive effect of climate-related shareholder resolutions on the probability of joining Climate Leaders suggest that firms are not joining because membership adds value to the firm; rather, these firms are joining CL because of pressures from shareholder activists. As described in Darnall, Henriques, and Sadorsky (2008) and Cañon-de-Francia and Garcés-Ayerbe (2009), environmental decisions made based on institutional pressures are not likely to lead to higher financial returns.

The paper is organized as follows. Section 2 provides a brief description of the CL and Ceres programs, the sampling procedure and characteristics of the sample firms. Section 3 describes our event study and reports the results from cross-sectional regressions of the announcements returns. The rival firm abnormal returns are analyzed in Section 4, while Section 5 examines the decision to join Climate Leaders. Lastly, Section 6 offers some concluding remarks.

\section{Sample Selection and Data Description}

This study focuses on two voluntary corporate environmental initiatives: EPA's Climate Leaders program and Ceres. We have chosen these programs because of their emphasis on voluntary commitments by firms to improve their environmental performance, and the promotional opportunities offered as one of the main benefits to their members.

\subsection{The Climate Leaders program and the Ceres Principles}

The EPA's Climate Leaders program is an industry-government partnership that works with companies to develop long-term strategies to reduce their impact on the climate. The CL corporate partners set aggressive 5-10 year goals for the reduction of greenhouse gases, and 
annually track and report their emissions to measure progress. ${ }^{3}$ In return, EPA provides technical assistance for the measurement and reporting of the firms' GHG emissions. The CL program, which started in 2002, requires its partners to conduct a careful inventory (quantity estimate) of their current GHG emissions before they commit to a specific reduction goal. The announcement of this goal usually follows within a year of the membership announcement. The goal is typically stated in percent reduction of total emissions, percent reduction of emissions per unit of output (KWh, dollar of revenue, production unit, tons produced, etc.), or a "net zero" goal. The latter implies that instead of decreasing its own pollution, the company pays for the reduction of another company's pollution or offsets its own pollution by planting trees or sponsoring clean energy projects, so called "offset projects”. ${ }^{4}$

Ceres is a national network of environmental organizations and other public interest groups that works with companies and investors to address sustainability challenges, including global climate change. The Ceres Principles is a ten-point code of corporate environmental conduct, dated 1989, that is publicly endorsed by companies as an environmental mission statement. ${ }^{5}$ Firms adopting the Ceres Principles pledge their dedication to environmental awareness and accountability, and commit to active continuous improvement, dialogue and systematic public reporting on their environmental progress. The Ceres Principles include reduction of pollution and waste, sustainable use of natural resources, energy conservation, and environmental restoration, as well as a commitment to inform the public and conduct a yearly self-evaluation of the progress in implementing the principles. Ceres provides advice on reporting and incident response, and helps communicate the company's environmental

\footnotetext{
${ }^{3}$ The Climate Leaders program focuses on the six major greenhouse gases: $\mathrm{CO}_{2}, \mathrm{CH}_{4}, \mathrm{~N}_{2} \mathrm{O}$, HFCs, PFCs, and $\mathrm{SF}_{6}$.

${ }^{4}$ Companies like the Carbon Fund and TerraPass specialize in arranging offset projects for greenhouse gases.

${ }^{5}$ It is possible for firms to agree to a subset of the 10 Ceres principles; however, in our data set of Ceres announcements, every firm agreed to the full set of Ceres principles.
} 
commitment to investors and the broader public. To enhance corporate accountability, the Ceres companies annually publish information on their environmental progress in corporate sustainability reports. ${ }^{6}$

In the context of voluntary environmental programs (VEPs) discussed in Khanna (2001), EPA's Climate Leaders program fall under the category of “public voluntary programs” which are facilitated by a government agency to encourage firms to reduce pollution. Ceres, on the other hand, fall under the category of "unilateral initiatives" that involve codes of conduct established by a non-governmental entity and therefore does not have direct government involvement. These programs therefore differ in terms of who is managing the program and the specific requirements of the program (e.g., specific targets versus overall conduct guidelines). Including both programs in our analysis will allow us to study the effects of these program differences.

\subsection{Sample selection}

The sample used in our analysis consists of 117 announcements over the period 1993-2008. We began with all 181 firms that joined the CL program ${ }^{7}$ and all 72 firms that joined the Ceres program over this time period, for a total of 253 firms. We then eliminate 59 firms that were listed outside the U.S. or privately held, leaving 195 firms. Searching Factiva and Lexis-Nexis Environmental for articles and press releases announcing that the company joins CL or Ceres, we are able to identify an exact announcement date for 148 of these 195 firms. Moreover, we find the subsequent announcement of a GHG reduction goal for 47 of the CL firms, for a total of 195 announcements. We next search Factiva, Lexis-Nexis Academic and Google Finance on the day

\footnotetext{
${ }^{6}$ For more information on CL and Ceres, see http://www.epa.gov/stateply/index.html and http://www.ceres.org.

${ }^{7}$ Eleven of these firms have since left the CL program. We have no information on the precise date of when these firms left the program or the reason behind these firms' decision to drop out of the program.
} 
of the announcement and the surrounding days (i.e., the event window) for articles and press releases with competing news that could potentially impact the stock price. This search eliminates 78 announcement observations due to the concomitant release of information on earnings, credit downgrades and other major corporate news on the day of the announcement through the next trading day, for a total sample of 117 announcements over the period 19932008.

Table 1 reports the distribution of the announcements over time and across the different programs. As shown in the table, the sample consists of 74 announcements by firms joining the Climate Leaders program and 20 announcements by firms joining the Ceres program. Moreover, there are 23 announcements by firms declaring their goal for the reduction of greenhouse gas emissions, of which 16 are also in our Climate Leaders sample. ${ }^{8}$ Most of the Ceres announcements take place in the 1990s, and 2006-07, while the number of CL and GHG announcements is relatively higher after 2006.

\subsection{Sample characteristics}

Table 2 presents financial and industry characteristics of the sample firms. We identify a total of 3,684 industry rivals (2,957 unique firm years) from the Center for Research in Security Prices (CRSP), defined as all firms with the same four-digit Standard Industrial Classification (SIC) industry code as the sample firm in the year of the announcement. Notice first that the sample firms are large when compared to other publicly traded firms in their industry. The average market value of equity six trading days prior to the announcement is $\$ 78$ billion (median $\$ 19$ billion) and total sales (from Compustat) averages $\$ 19$ billion (median $\$ 10$ billion) in the year

\footnotetext{
${ }^{8}$ This implies that 23-16=7 GHG reduction goal announcements are associated with CL firms whose CL membership announcement was eliminated from our original set of observations because of the lack of an exact announcement date or the existence of concomitant news occurring at or around the time of the CL membership announcement.
} 
prior to the announcement. Moreover, 91\% (94\%) of the sample firms have a market value (total sales) exceeding the median rival firm in its respective industry. The average market-to-book ratio (from Compustat, using the December closing price in the year prior to the announcement) is 3.7 (median 2.6). The sample firms have somewhat higher growth options than their industry rivals, with two-thirds of the firms having a market-to-book ratio above their respective industry median. Only $15 \%$ of the sample firms are traded on NASDAQ (versus the NYSE or Amex), another manifestation of the large size of firms joining Ceres and Climate Leaders.

Companies joining Climate Leaders and setting greenhouse gas goals are substantially larger than the firms in Ceres: the average market value of the CL firms is $\$ 93$ billion (median $\$ 28$ billion) compared to $\$ 13$ billion (median $\$ 3$ billion) for the Ceres firms. Moreover, almost all companies in Climate Leaders (96\%) have a market value exceeding their respective median industry rival, while two-thirds of the Ceres firms are larger than their respective industry median. The Ceres firms further have a slightly higher average book-to-market ratio than the firms in the CL group. The proportion of firms listed on NASDAQ, however, is similar across the three subsamples.

Table 2 also shows the number of rivals and the degree of industry concentration, indicating the level of competition in the industry. For our rival analysis, we construct portfolios of rival firms in the same four-digit SIC industry code as the announcing firm. There are on average 35 rival firms in each industry portfolio, with a median of 16 firms. Industry concentration is measured using the Herfindahl index, $H I=\sum_{j=1}^{n}\left(s_{j} / \sum_{j=1}^{n} s_{j}\right)^{2}$, where $s_{j}$ is the total sales of firm $j$, and $j=[1, n]$ is an index of all firms in the industry. The average Herfindahl index is 0.34 , with a median of 0.26 . Firms stating GHG goals are in the least concentrated (or most competitive) industries, with an average Herfindahl index of 0.25 (median 
0.11). Finally, a majority of the sample firms (57\%) are in the manufacturing industry, $16 \%$ in the transportation industry, and $9 \%$ in the finance industry, with the remaining $18 \%$ distributed across other industries. The proportion of firms in manufacturing is highest for the CL and GHG groups (59\% and 61\%, respectively) and lowest for Ceres (45\%), with a greater fraction of Ceres firms in transportation and finance.

\subsection{Environmental performance}

The degree to which firms rely on energy as an input to the production process varies across industries. We classify industries based on their overall use of fossil fuels, applying criteria from the Carbon Disclosure Project. ${ }^{9}$ One-half of the sample firms (53\%) are in industries with carbon-intensive production. Not surprisingly, the fraction of firms in carbon-intensive industries is lower for Ceres than for firms announcing a GHG reduction goal (45\% versus 61\%), reflecting the lower proportion of manufacturing firms joining Ceres. ${ }^{10}$ The majority of sample firms (70 firms or 60\%) are incorporated in a state participating in the Regional Greenhouse Gas Initiative (RGGI), while only three sample firms (3\%) are headquartered in a Western Climate Initiative (WCI) state, two of which joined the Ceres program.

We are able to find information on the initial goal for the reduction of greenhouse gas emissions from the firms’ sustainability reports for 19 firms joining Climate Leaders and for all 23 firms in the GHG sample. ${ }^{11}$ The average goal is a $16 \%$ reduction of greenhouse gases (median 15\%), with the smallest goal set at a $4 \%$ emission reduction. ${ }^{12}$ The most aggressive goal

\footnotetext{
${ }^{9}$ See http://www.cdproject.net/index.asp for more information on the Carbon Disclosure Project.

${ }^{10}$ Greenhouse gas emissions of individual firms are only available for a small sample of firms and for a few years. We therefore choose to rely on the industry classification to capture a firm's carbon-intensity in the cross-sectional analysis.

${ }^{11}$ For obvious reasons, Ceres firms do not report any goal for the reduction of greenhouse gas emissions.

${ }^{12}$ Greenhouse gas goals can come in various forms-e.g., \% reductions from a base year or level reductions. In order to be comparable, we have converted each firm's GHG goal to a \% reduction goal using data on the firm's actual GHG emissions.
} 
is set by United Technologies Corporation, who initially pledged to reduce its greenhouse gas emissions by $46 \%$ per dollar revenue over a five-year period. None of the sample firms have netzero goals involving the purchase of offset projects. The average company hopes to reach its emissions reduction goal in almost seven years. There is little difference between the firms in the CL and GHG samples with respect to the size of the announced greenhouse gas reduction goals and the time horizon reported to reach these goals.

KLD Research and Analytics, Inc. provides yearly assessments of company environmental performance in their product, KLD STATS. We use KLD STATS to gauge the environmental performance of the sample firms in the year prior to the announcement. KLD rates companies with a one (if present) or zero (if absent) in five areas of environmental strengths and seven areas of environmental concerns. ${ }^{13}$ The environmental strengths include revenue from environmental services, programs for pollution prevention, and the use of recycled materials and clean energy, while environmental concerns include liabilities for hazardous waste sites, violations of environmental regulations, manufacturing of ozone depleting and agricultural chemicals, emissions of toxic chemicals, and revenue derived from the sale of fossil fuels. As shown in Table 3, we focus on two environmental performance measures: the number of environmental strengths and the number of environmental concerns. We are able to identify KLD records for 99 sample firms and 1,246 unique industry-year rivals.

As shown in Table 3, the average firm ranks lower on its environmental strengths than its concerns ( 0.47 versus 0.79 ), reflecting the lower number of strengths than concerns (five versus seven). The companies in Ceres have a better overall pre-announcement environmental standing than firms in Climate Leaders, with a mean score of 0.43 for environmental concerns and 0.57

\footnotetext{
${ }^{13}$ There are a total of seven environmental strengths in KLD STATS. We exclude, however, two of the environmental strengths that are reported for only part of the sample period.
} 
for environmental strengths versus 0.81 for environmental concerns and 0.39 for environmental strengths in the case of the CL firms. Moreover, $87 \%$ of the Ceres firms have an environmental concerns score equal to or higher than their respective average industry rival.

Interestingly, the sample firms for GHG goals and Ceres rate significantly higher than their respective average competitor on environmental strengths. The highest average number of strengths (0.67) is associated with firms declaring a greenhouse gas reduction goal. There is no discernible difference between the sample firms and their rivals in the environmental concerns score. The Ceres firms, however, have on average fewer concerns than firms in the Climate Leaders program. Overall, the sample firms for GHG goals and Ceres have an environmental performance equal to or better than their average industry competitor in the year prior to the event.

Table 3 also shows how sample firms rank on two corporate governance characteristics, both from Risk Metrics. The first is the Gompers-Ishii-Metrick (GIM) index (from the Governance database), measuring the number of provision that restricts shareholders rights. The maximum number of such provisions is 18 and the higher the index the weaker are shareholder rights. ${ }^{14}$ We are able to obtain the GIM index for 96 of the sample firms. The average rank on the GIM index is 9.5 (median 9.0), ranging from a low of four to a high of 16 . The second measure is the number of shareholder proposals related to climate change filed in the year of and the year prior to the event (from the Shareholder Proposal database). Across all firms in the sample, the average number of climate-related proposals from shareholder activists is 0.12 .

\section{Shareholder Wealth Effects}

\footnotetext{
${ }^{14}$ For a detailed description of the GIM index, see Gompers, Ishii, and Metrick (2003).
} 
Why do firms join environmental initiatives like Climate Leaders and Ceres? A company may adopt a strategy for the reduction of greenhouse gas emissions without joining the Climate Leaders program. Similarly, high environmental standards could be applied without an official endorsement of the Ceres Principles. The public pledge to a reputable program could, however, help reduce information asymmetries with company outsiders—investors and customers—about the firm's environmental performance and commitment to the environment. This might be valuable if customer preferences are biased in favor of environmentally responsible suppliers, improving the firm's competitive position. It could also increase firm value by credibly conveying information about reductions in future energy and production costs, or in future environmental liabilities. On the other hand, if the expected costs of the necessary capital expenditure and enhanced accountability exceed the potential benefits, the initiative reduces firm value. In this case the decision to "go green" could potentially conflict with the directors' fiduciary duty to maximize shareholder wealth.

\subsection{Announcement abnormal returns}

To examine the valuation effect of voluntary corporate environmental programs, we estimate the announcement abnormal stock returns for the firms in our sample using an event study approach. ${ }^{15}$ The event study method has been used in more than 500 publications in top finance journals and its statistical properties are well-documented in the literature (Kothari and Warner, 2008). Its basic foundation is the efficient markets paradigm, assuming that the prices of financial securities are immediately updated to reflect news reaching the market. The magnitude of the abnormal stock performance at the time of an event offers a simple measure of the unanticipated impact of this event on the wealth of the firm's shareholders. An event study hence

\footnotetext{
${ }^{15}$ For a detailed statistical description of the event study methodology, see Appendix A.
} 
provides a natural experiment for assessing how the stock market values news on environmental initiatives. In particular, investors immediately incorporate in the stock price the net present value of all future expected cash flows associated with the announced initiative (costs and revenues).

In general, short-horizon event studies (similar to the one performed in this paper) are relatively straightforward and trouble-free. The method involves the estimation of a benchmark return. The abnormal return is the difference between the actual stock return and the return predicted by the benchmark model. This benchmark model could be based on one factor (the market return) or it could be more elaborate and include additional factors, such as book-tomarket (SMB), size (HML), and momentum. ${ }^{16}$ For short windows, the use of more elaborate pricing model typically makes little difference for the results (MacKinlay, 1997). Thus, in the paper, we explicitly report the results only for the standard (one-factor) market model.

Specifically, the abnormal return for firm $j$ on day $t$ is estimated as $\widehat{A R}_{j t}=R_{j t}-\left(\hat{\alpha}_{j}+\right.$ $\left.\hat{\beta}_{j} R_{m t}\right)$, where $R_{j t}$ is the return of the stock of firm $j$ on day $t ; R_{m t}$ is the equal-weighted market return on day $t$; and $\hat{\alpha}_{j}$ and $\hat{\beta}_{j}$ are the coefficients estimated from the single-factor market model $R_{j t}=\alpha_{j}+\beta_{j} R_{m t}+\epsilon_{j t}$ over days -253 through -3 . We require a minimum of 100 return observations in the estimation of the market model. The cumulative abnormal return for firm $j$ over the event window day -1 to +1 is $\widehat{C A R}_{j,-1,1}=\sum_{t=-1}^{1} \widehat{A R}_{j t}$; and the average cumulative abnormal return across the $N$ sample firms is $\widehat{A C A R}_{-1,1}=\frac{1}{N} \sum_{j=1}^{N} \widehat{C A R}_{j,-1,1}$.

The strength of the event study method lies in the precise definition of when the new information reaches the financial markets. Since it can be difficult to identify the exact trading day that the market reacts to the information, it is common practice to use a two or three-day

\footnotetext{
${ }^{16}$ See Fama and French (1993) and Carhart (1997).
} 
window around the event. The event window may be extended one or two days prior to the announcement to capture any information leakage. Similarly, the event window may also include one or two succeeding trading days to capture a delay from an announcement made after the closing of the market or a gradual update of the stock price. Extending the window, however, limits the possibility to attribute the change in value to the specific event. To avoid contamination, we restrict the sample to firms with no other announcements of substance in the event window. For this reason, the longer the event window, the smaller the number of observations.

Table 4 shows the average cumulative abnormal returns $(\widehat{A C A R})$ for the sample firms where 0 refers to the announcement date. In addition to the full sample, Table 4 also presents the results for a subsample that excludes announcements in fall 2008-the height of the U.S. financial crisis with extremely volatile stock markets. Excluding the fall 2008 announcements, $\widehat{A C A R}$ ranges from $-0.5 \%$ for the shorter $[0,1]$ event window to $-1.1 \%$ for the longer $[-2,2]$ event window, and is highly significant using alternative statistical tests. ${ }^{17}$ For the 58 firms joining Climate Leaders, the average drop in stock-market capitalization over the $[-1,1]$ event window is a hefty $\$ 3$ billion (excluding fall 2008). In the following, we focus mainly on this three-day window.

The stock market decline is greatest for firms joining Climate Leaders and for firms announcing greenhouse gas goals as part of their membership in Climate Leaders. These results are confirmed by the relatively low proportion of positive to negative returns: 19 positive versus 39 negative $\widehat{C A R}_{j,-1,1}$ for Climate Leaders and 4 versus 12 for the GHG goal. Thus, there is convincing evidence that shareholder value declines when firms announce their membership in

\footnotetext{
${ }^{17}$ We also compute the test statistics for a standard Patell test (Patell, 1976) and the non-parametric rank test (Corrado, 1989), both yielding similar inferences as the test statistics reported in Table 4 . The results of negative announcement returns also hold when using a value-weighted market index as well as a multi-factor benchmark model.
} 
Climate Leaders and again when a greenhouse goal is announced. Interestingly, the effect is stronger and more significant in recent years (i.e., 2006-2008), as seen by comparing the Climate Leader results for the periods 2002-2005 and 2006-2008.

The announcement return for firms endorsing the Ceres Principles is, however, indistinguishable from zero. It is possible that the lower level of commitment to environmental investments associated with the Ceres program compared to Climate Leaders makes investors less concerned with a Ceres membership. In contrast, the capital expenditure necessary to substantially reduce greenhouse gas emissions under the CL program may very well exceed the expected future profits from such reductions. It could also be the case that joining Ceres in the years prior to the introduction of the Climate Leaders may be interpreted as a more significant commitment to environmental initiatives. We, therefore, estimate the abnormal returns for Ceres announcement made before 2002 (when the Climate Leaders program was established) and after 2002. For both time periods, however, the estimated cumulative abnormal returns are indistinguishable from zero (not shown in the table).

\subsection{Cross-sectional determinants of the announcement returns}

The univariate analysis in Table 4 above suggests that investors are indifferent to broader, more diffuse, environmental initiatives like Ceres, but penalize companies for carbon-specific commitments required in programs such as the Climate Leaders program. However, not all firms experience the same stock price reaction to a decision to join Climate Leaders. To identify the firm characteristics most important for explaining variation in cumulative abnormal returns across the firms joining Climate Leaders and announcing a greenhouse gas goal, we conduct a cross-sectional analysis with $\widehat{C A R}_{j,-1,1}$ as the dependent variable. The regression is estimated with a weighted least square (WLS) regression, using the standard deviation of the residual of the 
market model as weights. This results in giving more weight to the more precise (less noisy) abnormal return estimates.

The preferences of customers and managers for voluntary environmental programs may have changed over time. Figure 1 plots the monthly frequency of U.S. press hits for keywords related to climate change over the period 1993-2008. The line represents the number of articles containing at least one of the following phrases: "climate leader", "climate change", and "global warming.” The figure shows how the public interest in climate change skyrocketed in 2005-2006 and remained at a high level in subsequent years. We include log of the total number of press hits related to climate change over the 12 months ending in the month prior to the announcement to capture these shifts in societal preferences for voluntary climate-related initiatives.

A reduction in greenhouse gas emissions typically requires a reduction in the use of fossil fuels. The higher the relative price of fossil fuels, the more valuable an improvement in energy efficiency is to the firm. The price of fossil fuels, such as oil, varies considerably over the sample period. As shown in Figure 2, the U.S. domestic crude oil price hovered around $\$ 10$ to $\$ 20$ per barrel through the 1990s, only to take off and reach record highs in recent years, similar to the development of the press index displayed in Figure 1. To capture variations in energy costs, the explanatory variables include the residual from a regression of climate press hits on average crude oil price over a three-month period ending the month prior to the announcement. ${ }^{18}$

Federal regulations of greenhouse gas emissions will most likely target industries that depend heavily on fossil fuels. If the pre-announcement stock price already reflects a higher probability of regulatory actions, the announcement of the environmental commitment should

\footnotetext{
${ }^{18}$ We use the residual in the regression to eliminate concerns that climate press hits and the crude oil price are highly correlated (confirmed by examining a correlation matrix). By using the residual, we are able to isolate the unique effects of variations in crude oil price. Crude oil prices are from the Monthly Energy Review of the U.S. Department of Energy/Energy Information Administration at http://www.eia.doe.gov/emeu/mer/petro.html.
} 
have less of an impact on firm value. To control for this, the regressions include an indicator for carbon-intensive industries. The regressions further control for firm characteristics such as size (represented by the market value of equity on day -6) and the market-to-book ratio. Moreover, it is possible that the extent of voluntary environmental investments is limited by industry competitive pressures. If industry competition prevents firms from making huge environmental capital expenditures, investors should be more concerned with the environmentally responsible investments of companies in concentrated industries. To capture this, the Herfindahl index is entered as a proxy for the degree of industry competition.

The regressions also include a dummy variable indicating that the firm's headquarters are located in a Regional Greenhouse Gas Initiative (RGGI) state. ${ }^{19}$ In an attempt to capture the effect of institutional pressures on investors' response to the firm's decision to join Climate Leaders, we include the number of shareholder proposals related to climate change in the year of and prior to the announcement, similar to Reid and Toffel (2009). The regressions also control for past environmental performance by entering the two KLD measures for the firm's environmental strengths and environmental concerns.

The response of investors to news of environmental initiatives may further be affected by corporate governance issues. If managers undertake value-reducing environmental investments for reasons of social responsibility, such commitments should be more common among firms with poor corporate governance standards. We therefore include the GIM index (discussed above), the KLD rankings of corporate governance strengths and weaknesses, and the fraction of the firm's shares owned by the board of directors (from Risk Metric's Directors database). The KLD corporate governance strengths include indicators for low levels of top management

\footnotetext{
${ }^{19}$ We did not include a dummy variable for firms located in the Western Climate Initiative (WCI) states since none of the firms included in the regression were incorporated in any of the WCI states.
} 
compensation and ownership strengths, while the concerns involve a high level of board and top management compensation and ownership concerns. ${ }^{20}$ Lastly, the regressions include a dummy variable if the announcement was made during the period 2006-2008 when we found the $\widehat{A C A R}$ s to be the most negative and significant.

Table 5 reports the coefficient estimates from the WLS regressions of the announcement cumulative abnormal return over the $[-1,1]$ event window $\left(\widehat{C A R}_{j,-1,1}\right)$. The sample comprises of 78 firms with available industry rival data from Compustat, necessary to compute the Herfindahl index. To test for robustness of the results, we conduct six regressions. Column 1 excludes the corporate governance and environmental indicators, and the time dummy. Column 2 includes the time dummy. Columns 3 and 4 add the GIM index to the column 1 and column 2 regressions, respectively. Lastly, columns 5 and 6 add the other corporate governance and environmental measures to the column 3 and 4 regressions, respectively. The sample size shrinks to $N=65$ as data on the GIM index is required (Columns 3-4), and to $N=61$ when KLD records and board share ownership is added (Columns 5-6). The regressions are significant with an adjusted $\mathrm{R}^{2}$ ranging from $15 \%$ to $29 \%{ }^{21}$

There are several interesting results. In the first two regressions, the announcement returns significantly increase with the crude oil price. That is, programs diminishing the dependence on fossil fuels have a greater value when energy prices are high, reducing the expected net loss from the investment. However, this effect goes away when we add the GIM corporate governance index, suggesting that these two variables are correlated-i.e., the trend in crude oil prices is coincident with the trend in corporate governance standards. The variable for

\footnotetext{
${ }^{20}$ Several of the KLD variables for corporate governance strengths and concerns were not defined before the mid 2000s. Our measures are each limited to the three dimensions that are reported for the whole period 2002-2008.

${ }^{21}$ Since the decision to join Climate Leaders is voluntary, these coefficient estimates may be biased. While not reported here, we also conduct a Heckman two-step procedure to correct for such self-selection (Heckman, 1979; Maddala, 1983) and find that the main inferences hold.
} 
the press coverage of climate change produces a significantly positive coefficient across all the regressions except for when the time dummy is included in the last regression. Thus, in contrast to what may appear from the univariate results in Table 4, the stock price decline is greater in periods of low interest from the general public in climate change, all else equal. This suggests that when public concern about climate change is highest, firms take a lesser hit to their stock price from joining Climate Leaders. We'll return to this supposition in Section 5 below when examining the characteristics of firms that chose to join these programs.

Moreover, firms with higher market-to-book ratios (i.e., more growth options) experience a greater decline in their stock price, suggesting that voluntary environmentally responsible investments are interpreted by investors to be more costly for growth firms. ${ }^{22}$ An investor's belief that future greenhouse gas reduction goals may be more difficult to achieve if a firm is expected to grow fast or that the reallocation of resources away from positive net present value projects is more problematic for high-growth firms are among the possible explanations for this result. ${ }^{23}$ Alternatively, the environmental investments may signal that the firm has fewer positive net present value projects than previously anticipated by investors (see e.g. McConnell and Muscarella, 1985), resulting in more serious implications for the valuation of firms with a large fraction of their value attributable to growth options.

Of the corporate governance variables, only the GIM index is significant. The negative coefficient associated with the GIM index suggests that the more hostile a firm's governance structure is to shareholders, the greater the hit to the firm's stock price from joining Climate

\footnotetext{
${ }^{22}$ In contrast, stock abnormal returns are found to increase with the market-to-book ratio for corporate announcements of R\&D expenditures. See e.g. Szewczyk, Tsetsekos, and Zantout (1996).

${ }^{23}$ Distinguishing between these two explanations is difficult since it would not necessarily require knowledge of each firm's underlying motivation for joining Climate Leaders but rather information on what investors believe is the firm's motivation at the time of the CL announcement. Similarly, examining what occurs at the firm level after the announcement (e.g., changes in investment strategies; declines in operating performance; firing of personnel) is not likely to assist in disentangling these alternative hypotheses since the change in stock price at the time of the announcement is based on investors' expectations of future firm performance, which may or may not transpire.
} 
Leaders. The coefficient associated with the RGGI dummy variable is negative but only significant when the regression includes the GIM index and excludes the other corporate governance and environmental performance measures (columns 3 and 4). The negative coefficient suggests that firms located in an RGGI state experience a larger decline in stock price. This seems counter to intuition which would tell us that the stock prices of firms in RGGI states already reflect an expectation that mitigation costs will be incurred; however, RGGI only affects the power sector in these states. Thus, a decision by other firms in these states to voluntarily reduce GHG emissions is considered by investors to impose a greater cost on the firm (than on firms located in other states) perhaps because it signals to policymakers in these states-policymakers with an inclination to regulate greenhouse gas emissions-that broader climate change regulation may be politically feasible.

Of the environmental performance variables, neither the measure of environmental strengths nor the measure of environmental concerns produces significant coefficients. The dummy for carbon intensive industry, the degree of industry concentration (the Herfindahl index) and the number of climate-related shareholder resolutions also have no significant effect on a firm's announcement returns.

\section{Wealth Effects for Rival Firms}

Investors react negatively when the firm announces its membership in the Climate Leaders program and again on the announcement of its goals for GHG reduction. The valuation impact on its industry rivals is, however, uncertain. The announcement may simply convey information about a poor investment decision made by the firm, having little or even a positive effect on the valuation of industry competitors. Alternatively, as suggested by our above results related to the RGGI states and as raised in Reinhardt (1999), a voluntary commitment to CL or Ceres could 
spur governmental regulations, increasing the likelihood of industry-wide changes in the cost structure, with negative valuation implications for all firms in the industry. ${ }^{24}$

To address this issue, we form equal-weighted portfolios of all industry rivals of each sample firm and estimate the cumulative abnormal returns $\widehat{C A R}_{r}$ for the rival portfolios $r$, as described above. The average $\widehat{C A R}_{r}$ over the different event-windows and subsamples are reported in Table 6. Except for the rivals of firms announcing GHG goals, the average cumulative abnormal stock returns for the rival portfolios are insignificant from zero. This holds for rivals of firms joining Climate Leaders as well as Ceres, and for all three event windows. ${ }^{25}$ The insignificant stock price reaction for rival firms suggests that the average membership in Climate Leaders or Ceres does not materially increase the anticipated likelihood of future environmental regulations, nor does it appear to provide a competitive advantage to the sample firms over their rivals.

In the case of rivals of firms announcing GHG goals, however, we document a significant and negative $\widehat{A C A R}$. This implies that firms who commit to specific reductions, which imply a stronger commitment to reducing GHGs, are causing investors to also penalize rival firms in the same industry, perhaps suggesting that investors will adjust upwards their expectations of future regulations that may affect the cost-structure for all firms in the industry.

\section{The Voluntary Nature of Environmental Initiatives}

A caveat with any study of voluntary corporate decisions is that the sample firms self-select the event. One cannot entirely rule out the possibility that the initiative in fact reveals some other

\footnotetext{
${ }^{24}$ Industry rivals are affected by new information concerning the industry cost structure, customer demand, etc. See e.g. Jarrell and Peltzman (1985) for evidence that competitors of auto and drug companies announcing product recalls suffer significant stock price declines (as do the firms themselves).

${ }^{25}$ The rival portfolio $A C A \hat{R}$ s are insignificant from zero also when using a value-weighted market portfolio or a multi-factor benchmark model.
} 
information about the firm. Choosing to join Climate Leaders could thus be correlated with negative information, without necessarily implying that the environmental investment itself is value reducing. As discussed in the introduction, some firms might be joining these programs to offset concurrent news that is negative. As long as the concurrent news is also made public at the same time, these firms are eliminated from our sample. As discussed in Section 2.2, 78 announcements were eliminated due to other substantial concurrent news. Examining the concurrent news releases associated with these 78 announcements we find, to the contrary, that the concurrent news was largely positive-i.e., 53 were positive, 17 were negative, and 13 could not be classified. This ratio of positive to negative news is consistent with the well-known fact that most company announcements tend to contain positive news (e.g., see Davis, Piger, and Sedor, 2008), and thus does not suggest any attempts to hide negative information through the program announcement.

Moreover, the fact that relatively few firms have chosen to join Climate Leaders-around three percent of publicly traded firms are members of CL—further suggests that the potential gains from such a membership are perceived to be limited or negative. If this is the case, the compelling question is why are firms joining programs like Climate Leaders? Reid and Toffel (2009) suggest that institutional pressures may induce companies to join environmental programs even though it implies a reduction in firm value. We test this hypothesis by conducting a probit analysis to identify the key factors driving the choice to join the Climate Leaders program.

\subsection{The decision to join Climate Leaders}

Table 7 reports probit estimations of a firm's decision to join Climate Leaders. The regressions are significant with a pseudo (Nagelkerke) $\mathrm{R}^{2}$ ranging from $16 \%$ to $27 \%$. We restrict the analysis to rival firms within the same 4-digit industry and year as the sample firms. The sample is 78 
firms in the CL program as well as 1,237 unique industry-year rivals with available Compustat data. ${ }^{26}$ The first two columns exclude the KLD measures, the GIM index, and the board stock ownership fraction, and are run with and without the time dummy 2006-08. The third and fourth columns replicate columns one and two, respectively, but include the GIM index, for a reduced sample of 65 CL firms and 465 rivals. Lastly, columns five and six replicate the regressions in columns three and four, but include the KLD environmental and corporate governance measures and the fraction board stock ownership, for an even smaller sample of 61 CL firms and 356 industry rivals. In addition to the variables used in Table 5, we include a dummy indicating whether or not the firm is listed on NASDAQ (versus NYSE or Amex).

A number of interesting results emerge from these regressions. First, in support of the findings of Reid and Toffel (2009), we find that firms with a higher number of shareholder proposals targeted at issues related to climate change have a significantly higher probability of joining Climate Leaders. Combined with the earlier evidence of negative announcement returns, this is consistent with the notion that shareholder activists may push for such voluntary environmental commitments even if it reduces firm value. Controlling for climate-related shareholder resolutions, we find that firms with poorer corporate governance standards are more likely to join, as evident from the positive and significant coefficients associated with the GIM index and the KLD measure for corporate governance concerns (column 6). The remaining governance variables are insignificant.

It is also the case that firms listed on NASDAQ are less likely to join, consistent with the summary statistics in Table 2 above, which shows that the sample firms are typically larger than their industry rivals. It is possible that the larger firms have more widely-spread share ownership

\footnotetext{
${ }^{26}$ The sample includes seven firms announcing a greenhouse gas goal that were excluded from the CL sample above because their announcement to join the Climate Leaders program is corrupted by concurrent news, or we are unable to exactly determine this date.
} 
and therefore an inherently greater conflict of interest between management and the owners of the firm. Interestingly, for companies listed on a given stock exchange, the firms with a relatively high market value of equity (e.g., larger firms) are less likely to join.

Moreover, companies that score relatively high on environmental strengths are more likely to join. That is, firms choosing to join CL have already committed substantial resources to their environmental performance prior to these programs, consistent with the notion that management takes a special interest in environmental investments. When the 2006-08 time dummy is left out, we find that firms are more likely to join Climate Leaders when climate press hits are high. When the time dummy is included, firms are generally less likely to join Climate Leaders when press hits are high, and the time dummy itself is positive and significant. Therefore, it seems that a firm's motivation to join a program like Climate Leaders has more to do with factors correlated with the passage of time than climate press hits, specifically. The time dummy also has an effect on the significance of the crude oil price variable-namely, crude oil price is negative and significant in the regressions without the time dummy and insignificant when the time dummy is added. In other words, when the time dummy is not included, companies seem to ignore the potential for cost savings from a reduction of greenhouse gas emissions in their decision to join Climate Leaders. Again, this supports the view that considerations other than shareholder wealth, like social responsibility, motivates management to voluntarily make a commitment to CL.

In sum, even though joining a program like Climate Leaders may not make sense from a shareholder value maximization point of view—as evident from our event study results in Table 4-there could be other reasons why firms may be joining, as suggested by our probit results. First, firms may be joining the program in response to institutional pressures—reflected, for 
instance, in the number of climate-related proposals by shareholder activists. Second, for a given level of shareholder resolutions associated with climate change, the firm's management might decide to join for reasons other than to add value and is able to make such a decision due to the lack of oversight from its shareholders. This second explanation is consistent with our additional findings that firms which rank relatively high on their environmental strengths are more likely to join: management may have a desire to further improve the environmental performance of the firm regardless of the effect on firm value.

\section{Conclusions}

Climate change may prove to be one of the gravest environmental challenges of this century. U.S. emissions and climate policy are of central importance to this issue, as the U.S. accounts for one quarter of global greenhouse gas emissions. However, efforts to limit U.S. emissions through international treaties, such as the Kyoto Protocol, or through federal regulations have routinely been defeated. The current U.S. federal climate policy relies entirely on voluntary reductions of corporate emissions, assisted by programs such as the EPA's Climate Leaders program. The success of these voluntary programs depends on their ability to achieve meaningful company participation. Since broad corporate participation will ultimately depend on the wealth implications for shareholders, it is crucial to examine the market response to such initiatives, conveying information about whether it pays for companies to participate in these programs.

Our study is one of the first to address this question with respect to climate initiatives. Previous studies on the relationship between environmental and financial performance have produced mix results. However, in general it appears that in cases where environment performance is tied to liability, compliance, and regulatory risks, environmental performance and financial performance tend to have a positive relationship. Thus, in these cases, investors are 
interpreting the environmental investments made by the firm to be adding firm value whereas in other cases such investments are interpreted as value reducing. How do investors view environmental investments related to climate change? Our study hopes to shed light on this question.

Contrary to some of these earlier studies, our event study results show significant losses in the market value of firms announcing that they join Climate Leaders and at their subsequent announcement of a greenhouse gas emissions reductions goal. In contrast, firms announcing an endorsement of the Ceres Principles experience insignificant stock returns, possibly because the Ceres program involves less specific commitments to environmental investments. For companies joining Climate Leaders or announcing a greenhouse gas reduction goal, we find that the stock price decline is larger for firms with weak corporate governance structures, suggesting that managers have greater discretion to make investment decisions that may not be in the interest of shareholders. We also find that the stock price declines in the market-to-book ratio, perhaps indicating that climate-related investments send a negative signal about the investment opportunity set for high-growth firms. The program announcements further have no statistically significant average valuation effects on portfolios of industry rival firms, suggesting that the expectation of future regulation is unaffected by additional companies signing up for Climate Leaders and Ceres.

Given the significantly negative impact on stock price from Climate Leaders membership, what are some possible explanations for why firms would join? Our probit analysis shows that firms with a higher number of shareholder resolutions directed at climate change are more likely to join the Climate Leaders program. Controlling for these resolutions, we also find that firms with weak corporate governance structures are more likely to join. Thus, it seems that 
firms are entering the Climate Leaders program despite the prospect of lowering shareholder value either because they are facing institutional pressures to do so, or because managers face less shareholder oversight, allowing them more discretion to make these types of voluntary environmentally responsible investment decisions.

Our finding of a negative market response to Climate Leaders membership has important implications for the success of voluntary environmental programs and potentially for the need to regulate GHG emissions. Importantly, the results indicate that voluntary environmentally responsible investments of this kind conflict with firm value maximization. Indeed, firms joining Climate Leaders are characterized by relatively poor corporate governance standards and a high number of shareholder resolutions targeted at climate change. Our evidence suggests that the social costs of climate change may not be internalized by corporations. In light of such market failure, federal regulation or taxation may prove to be the only viable way to achieve a broad reduction of greenhouse gas emissions in the U.S. 


\section{References}

Anton, Wilma Rose Q., George Deltas, and Madhu Khanna, 2004, “Incentives for environmental self-regulation and implications for environmental performance,” Journal of Environmental Economics and Management, 48, 632-654.

Boehmer, Ekkehart, Jim Musumeci, and Annette B. Poulsen, 1991, ”Event-study methodology under conditions of event-induced variance,” Journal of Financial Economics 30(2), 253272.

Brouhle, Keith, Charles Griffith, and Ann Wolverton, 2009, "Evaluating the role of EPA policy levers: An examination of a voluntary program and regulatory threat in the metal-finishing industry,” Journal of Environmental Economics and Management, 57, 166-181.

Cañon-de-Francia, Joaquín, and Concepción Garcés-Ayerbe, 2009, “ISO 14001 environmental certification: A sign valued by the market?” Environmental and Resource Economics, 44(2), 245-262.

Carhart, Mark M., 1997, “On persistence in mutual fund performance,” Journal of Finance 52(1), 57-82.

Clarkson, Peter M., and Yue Li, 2004, “The market valuation of environmental capital expenditures by pulp and paper companies,” The Accounting Review 79(2), 329-353.

Cohen, M.A., S.A. Fenn, and S. Konar, 1997, "Environmental and financial performance: are they related?” Manuscript. Vanderbilt University, Nashville, TN.

Cowan, Arnold R., 1992, “Nonparametric event study tests,” Review of Quantitative Finance and Accounting 2, 343-358

Cormier, Denis, Michael Magnan, and Bernard Morard, 1993, “The impact of corporate pollution on market valuation: some empirical evidence,” Ecological Economics 8, 135155.

Corrado, Charles J., 1989, “A nonparametric test for abnormal security-price performance in event studies,” Journal of Financial Economics 23, 389-395.

Davis, Piger, and Sedor, 2008, “Beyond the Numbers: Managers’ Use of optimistic and pessimistic tone in earnings press releases,” manuscript, Lundquist College of Business, University of Oregon.

Darnall, Nicole, Irene Henriques, and Perry Sadorsky, 2008, “Do environmental management systems improve business performance in an international setting?” Journal of International Management, 14(4), 364-376.

Dasgupta, Susmita, Jong Ho Hong, Benoit Laplante, and Nlandu Mamingi, 2006, “Disclosure of environmental violations and stock market in the Republic of Korea,” Ecological Economics 58(4), 759-777. 
Derwall, Jeroen, Nadja Guenster, Rob Bauer, and Kees Koedijk, 2005, “The eco-efficiency premium puzzle,” Financial Analysts Journal 61(2), 51-63.

Fama, Eugene F., 1970, "Efficient capital markets: a review of theory and empirical work", Journal of Finance 25, 383-417.

Fama, Eugene F., and Kenneth R. French, 1993, "Common risk factors in the returns on stocks and bonds,” Journal of Financial Economics 33(1), 3-56.

Geczy, Christopher C., Robert F. Stambaugh, and David Levin, 2005, "Investing in socially responsible mutual funds," Working paper, University of Pennsylvania.

Guenster, Nadja, Jeroen Derwall, Rob Bauer, and Kees Koedijk, 2006, "The economic value of corporate eco-efficiency,” manuscript, RSM Erasmus University, Rotterdam, The Netherlands.

Gompers, Paul, Joy Ishii, and Andrew Metrick, 2003, “Corporate governance and equity prices,” The Quarterly Journal of Economics, 107-155.

Gupta, Shreekant, and Bishwanath Goldar, "Do stock markets penalize environment-unfriendly behavior? Evidence from India,” Ecological Economics 52(1), 81-95.

Hamilton, James T., 1995, "Pollution as news: media and stock market reactions to the Toxics Release Inventory data," Journal of Environmental Economics and Management 28, 98113.

Hart, Stuart L. and Gautam Ahuja, 1996, "Does it pay to be green? An empirical examination of the relationship between emission reduction and firm performance," Business Strategy and the Environment 5, 30-37.

Heckman, James J., 1979, “Sample selection bias as a specification error,” Econometrica 47, $153-161$.

Jaggi, Bikki, and Martin Freedman, 1992, "An examination of the impact of pollution performance on economic and market performance: pulp and paper firms," Journal of Business Finance \& Accounting 19(5), 697-713.

Jarrell, Gregg, and Sam Peltzman, 1985, "The impact of product recalls on the wealth of sellers," Journal of Political Economy 93, 512-536.

Khanna, Madhu, 2001, “Non-Mandatory Approaches to Environmental Protection,” Journal of Economic Surveys, 15(3), 291-324.

Khanna, Madhu, and Lisa A. Damon, 1999, "EPA's voluntary 33/50 program: Impact on toxic releases and economic performance of firms," Journal of Environmental Economics and Management, 37: 1-25.

King, Andrew A. and Michael J. Lenox, 2001, "Does it really pay to be green? An empirical study of firm environmental and financial performance,” Journal of Industrial Ecology 5(1), 105-106. 
Klassen, Robert D. and Curtis P. McLaughlin, 1996, “The impact of environmental management on firm performance,” Management Science 42(8), 1199-1214.

Konar, Shameek and Mark A. Cohen, 2001, "Does the market value environmental performance?” The Review of Economics and Statistics 83(2), 281-289.

Kothari, S.P. and Jerold B. Warner, 2008, “Econometrics of event studies,” Chapter 1 in Espen Eckbo, Ed., Handbook of Empirical Corporate Finance, Elsevier-North-Holland.

Kramer, Lisa, 2001, “Alternative methods for robust analysis in event study applications,” Advances in Investments Analysis and Portfolio Management 8, 109-132.

Lyon, John D., Brad M. Barber, and Chih-Ling Tsai, 1999, “Improved methods for tests of longrun abnormal stock returns,” Journal of Finance 54(1), 165-201.

MacKinlay, A. Craig, 1997, “Event Studies in Economics and Finance,” Journal of Economic Literature, 35(1), 13-39.

Maddala, G.S., 1983, “Limited-Dependent and Qualitative Variables in Econometrics,” Econometric Society Monographs 3 (Cambridge University Press).

McConnell, John J., and Chris J. Muscarella, 1985, “Corporate capital expenditure decisions and the market value of the firm,” Journal of Financial Economics 14(3), 399-422.

McWilliams, Abagail, and Donald S. Siegel, 1997, "Event studies in management research: theoretical and empirical issues,” Academy of Management Journal 40, 626-658.

Molloy, Linsey, Homer Erekson, and Raymond Gorman, 2002, "Exploring the relationship between environmental and financial performance,” Unpublished Manuscript, Miami University.

Palmer, Karen, Wallace E. Oates, and Paul R. Portney, 1995, “Tightening environmental standards: the benefit-cost or the no-cost paradigm,” Journal of Economic Perspectives 9(4), 119-132.

Patell, James M., 1976, “Corporate forecasts of earnings per share and stock price behavior: empirical tests,” Journal of Accounting Research 14(2), 246-274.

Porter, Michael E. and Claas van der Linde, 1995, “Toward a new conception of the environment-competitiveness relationship,” Journal of Economic Perspectives 9(4), 97118.

Reid, Erin M., and Michael W. Toffel, 2009, "Responding to public and private politics: corporate disclosure of climate change strategies,” Harvard Business School, Working Paper 09019.

Reinhardt, Forest, 1999, “Bringing the environment down to earth,” Harvard Business Review, July-August 1999, 149-157. 
Russo, Michael V. and Paul A. Fouts, 1997, "A resource-based perspective on corporate environmental performance and profitability,” Academy of Management Journal 40(3), 534-559.

Sharpe, William F., 1964, "Capital asset prices: A theory of market equilibrium under conditions of risk”, Journal of Finance 19(3), 425-442.

Szewczyk, Samuel, George Tsetsekos, and Zaher Zantout, 1996, "The valuation of corporate R\&D expenditures: Evidence from investment opportunities and free cash flow," Financial Management 25(1), 105-110.

Telle, Kjetil, 2006, “It pays to be green-A premature conclusion?” Environmental \& Resource Economics 35, 195-220.

White, Mark, 1996, “Corporate environmental performance and shareholder value,” Working paper, University of Virginia.

Walley, Noah and Bradley Whitehead, 1994, "It’s not easy being green.” Harvard Business Review 72(3), 46-52.

Ziegler, Andreas, Timo Busch, and Volker H. Hoffman, 2009, "Corporate Responses to Climate Change and Financial Performance: The Impact of Climate Policy,” Working Paper 09/105, Center of Economic Research at ETH Zurich. 


\section{Appendix A: The event study method and test statistics}

\section{A.1 Abnormal returns and the benchmark model}

The event study methodology is widely used in the area of financial economics. Its foundation is the efficient markets hypothesis, which assumes that the prices of financial securities immediately reflect news reaching the market (Fama 1970). Under this hypothesis, the magnitude of the abnormal stock performance at the time of a corporate event provides a measure of the (unanticipated) impact of this event on the wealth of the firm's shareholders. For a detailed review of the event study method and its statistical properties, see e.g. MacKinlay (1997) and Kothari and Warner (2008).

The abnormal stock performance is measured relative to that predicted by a benchmark model. The traditional benchmark is the market model, which establishes a linear relationship between the return of an individual stock and that of the stock market portfolio (Sharpe 1964). Let $R_{m t}$ be the return of the market portfolio and $R_{j t}$ be the return of the common stock of firm $j$ on trading day $t$ relative to the event (for which $t=0$ ), then the market model is

$$
R_{j t}=\alpha_{j}+\beta_{j} R_{m t}+e_{j t}
$$

Here, $e_{j t}$ is an independent and identically distributed error term associated with firm $\mathrm{j}$ on day $t$, with $E\left(e_{j t}\right)=0$ and $\operatorname{Var}\left(e_{j t}\right)=s_{j t}^{2}$. By construction, $s_{j t}$ is assumed to be uncorrelated with $R_{m t}$ and uncorrelated with $R_{k t}$ for $k \neq j$. Further, $\alpha_{j}$ and $\beta_{j}$ are the parameters of the market model for firm $j$. In this study, we construct the market portfolio from all U.S. publicly traded firms in the Center for Research in Securities Data (CRSP) included with equal weights. We use an ordinary least square (OLS) regression to estimate the market model over the year preceding the an- 
nouncement, with an estimation period from $t=-253$ through $t=-3$. We require the firm's stock to be traded on at least 100 days in the estimation period. ${ }^{27}$

The abnormal return $\widehat{A R}_{j t}$ (the prediction error) for firm $j$ on day $t$ in the event-window is the difference between the actual return and that predicted by the market model, i.e.

$$
\widehat{A R}_{j t}=R_{j t}-\left(\hat{\alpha}_{j}+\hat{\beta}_{j} R_{m t}\right) .
$$

The event window includes two or more days; where $t=T_{1}$ and $t=T_{2}$ is the first and last day in the event window, respectively, and $T_{1}<T_{2}$. The abnormal returns can be accumulated over the days in the event window, such that the cumulative abnormal return for firm $j$ is

$$
\widehat{C A R}_{j, T_{1}, T_{2}}=\sum_{t=T_{1}}^{T_{2}} \widehat{A R}_{j t}
$$

Finally, the average cumulative abnormal return across the $N$ sample firms is

$$
\widehat{C A R}_{T_{1}, T_{2}}=\frac{1}{N} \sum_{j=1}^{N} \widehat{C A R}_{j, T_{1}, T_{2}} .
$$

We estimate and report the average cumulative abnormal return for three different event windows: $t \in[0,1],[-1,1]$ and $[-2,2]$. Expanding the event window with one or two days provides some flexibility as to when the information reaches the market, but is still short enough to exclude confounding news. ${ }^{28}$

Recent studies of environmental events by, e.g., Gupta and Goldar (2005), Dasgupta, Ho, Laplante, and Mamingi (2006) and Canon-de-Francia and Garces-Ayerbe (2009) use the market model as the benchmark. In robustness tests (not presented in the paper), we estimate the abnormal returns relative to a four-factor model including the two factors (SMB and HML) proposed by Fama and French (1993) and the momentum factor introduced by Carhart (1997). For

\footnotetext{
${ }^{27}$ This restriction is not binding for any of the sample firms.

${ }^{28}$ See, e.g., McWilliams and Siegel (1997) for a discussion of the length of the event window.
} 
the short event windows used in this paper, the inferences from the four factor model are largely the same as those from the single-factor market model.

\section{A.2 Test statistics and their properties}

It is not uncommon that the cross-sectional dispersion of stock returns increases around an event. The parametric test proposed by Patell (1976) deals with such event-induced variance by standardizing each abnormal return $\widehat{A R}_{j t}$ with its estimated standard deviation $\hat{S}_{j t}$ to get an estimated standardized abnormal return (or standardized prediction error)

$$
\widehat{S A R}_{j t}=\frac{\widehat{A R}_{j t}}{\hat{S}_{j t}}
$$

The maximum likelihood estimate of the standard deviation $\hat{S}_{j t}$ is

$$
\hat{S}_{j t}=\sqrt{\frac{\sum_{t=-253}^{-3} \widehat{A R}_{j t}^{2}}{M_{j}-2}\left[1+\frac{1}{M_{j}}+\frac{\left(R_{m t}-\bar{R}_{m}\right)^{2}}{\sum_{t=-253}^{-3}\left(R_{m t}-\bar{R}_{m}\right)^{2}}\right]},
$$

where $M_{j}$ is the number of non-missing trading day returns for stock $j$ in the estimation period, $R_{m t}$ is the observed return on the market index on day $t$, and $\bar{R}_{m}$ is the average market return over the estimation period of firm $j$.

Under the null hypothesis, each $\widehat{S A R} R_{j t}$ follows a Student's t distribution with $M_{j}-2$ degrees of freedom. The test statistic for the null hypothesis that $\widehat{A C A R}_{T_{1}, T_{2}}=0$ is

$$
Z_{T_{1}, T_{2}}=\frac{1}{\sqrt{N}} \sum_{j=1}^{N} \frac{\sum_{t=T_{1}}^{T_{2}} \widehat{S \widehat{A} R_{j t}}}{\sqrt{\left(T_{2}-T_{1}+1\right) \frac{M_{j}-2}{M_{j}-4}}}
$$

which is distributed unit normal under $H_{0}$ for large $N$.

We compute the standard Patell test as well as a bootstrapped Patell test. The latter performs non-parametric bootstrapping to determine the significance level, adjusting the Patell test 
for serial dependence in both parametric and bootstrap results. The bootstrap tests are performed for the various event windows. For a detailed discussion of the bootstrap method in event studies, see Kramer (2001) and Lyon, Barber and Tsai (1999). In our event study, the Patell test statistics are merely marginally affected by the bootstrapping. Thus, for expositional purposes, we report only the bootstrapped Patell test.

Boehmer, Musumeci and Poulsen (1991) introduce an extension of the Patell test called the standardized cross-sectional test. This test compensates for a possible increase in the dispersion of stock returns on the event date by incorporating a cross-sectional variance adjustment. The test is the same as the Patell test described above except that there is a final empirical crosssectional variance adjustment in place of the analytical variance of the total standardized prediction error. The estimation-period standard deviation (adjusted for forecast error) is

$$
\widehat{U}_{j, T_{1}, T_{2}}=\sqrt{\frac{\sum_{t=-253}^{-3} \widehat{A R}_{j t}^{2}}{M_{j}-2} L_{j}\left[1+\frac{L_{j}}{M_{j}}+\frac{\sum_{t=T_{1}}^{T_{2}}\left(R_{m t}-L_{j} \bar{R}_{m}\right)^{2}}{\sum_{k=1}^{M_{j}}\left(R_{m k}-\bar{R}_{m}\right)^{2}}\right]}
$$

where $L_{j}=T_{2}-T_{1}+1$ is the number of days in the event period. Define the standardized cumulative abnormal return for stock $j$ as

$$
\widehat{\operatorname{SCAR}}_{j, T_{1}, T_{2}}=\frac{\widehat{C A R}_{j, T_{1}, T_{2}}}{\widehat{U}_{j, T_{1}, T_{2}}}
$$

The standardized cross-sectional test statistic for the null hypotheses that $\widehat{A C A R}_{T_{1}, T_{2}}=0$ is then

$$
Z_{T_{1}, T_{2}}=\frac{\sum_{j=1}^{N} \widehat{S C A R}_{j, T_{1}, T_{2}}}{\sqrt{\frac{N}{N-1} \sum_{i=1}^{N}\left(\widehat{S C A R}_{i, T_{1}, T_{2}}-\frac{1}{N} \sum_{j=1}^{N} \widehat{S C A R}_{j, T_{1}, T_{2}}\right)^{2}}}
$$

again distributed unit normal for large $N$. 
The tables finally report the p-value from a generalized sign test developed by Cowan (1992). This test controls for the normal asymmetry of positive and negative cumulative abnormal returns $\left(\widehat{C A R}_{j, T_{1}, T_{2}}\right)$ in the event period $T_{1}$ through $T_{2}$. 
Figure 1: Intensity of U.S. press articles on climate change, 1993-2008

The graph shows the monthly number of U.S. press hits in Factiva for the words "climate leader", "climate change", or "global warming", 1993-2008.

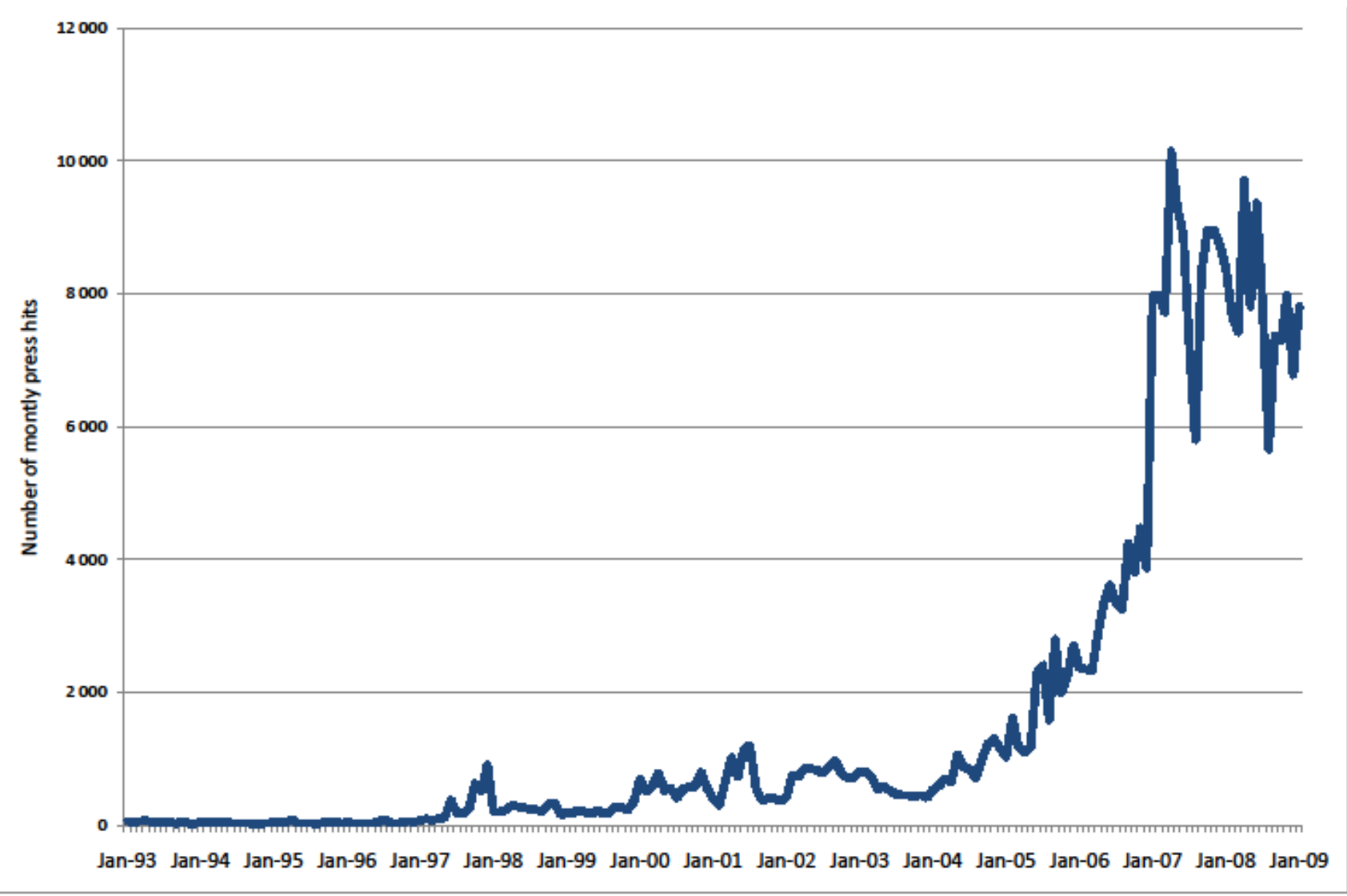


Figure 2: U.S. domestic crude oil price, 1993-2008

The graph shows the 3-month moving average of the crude oil price in \$ per barrel, 1993-2008. The price is the domestic first price from the U.S. Department of Energy/Energy Information Administration's Monthly Energy Review. Available at http://www.eia.doe.gov/dnav/pet/pet_pri_dfp1_k_m.htm.

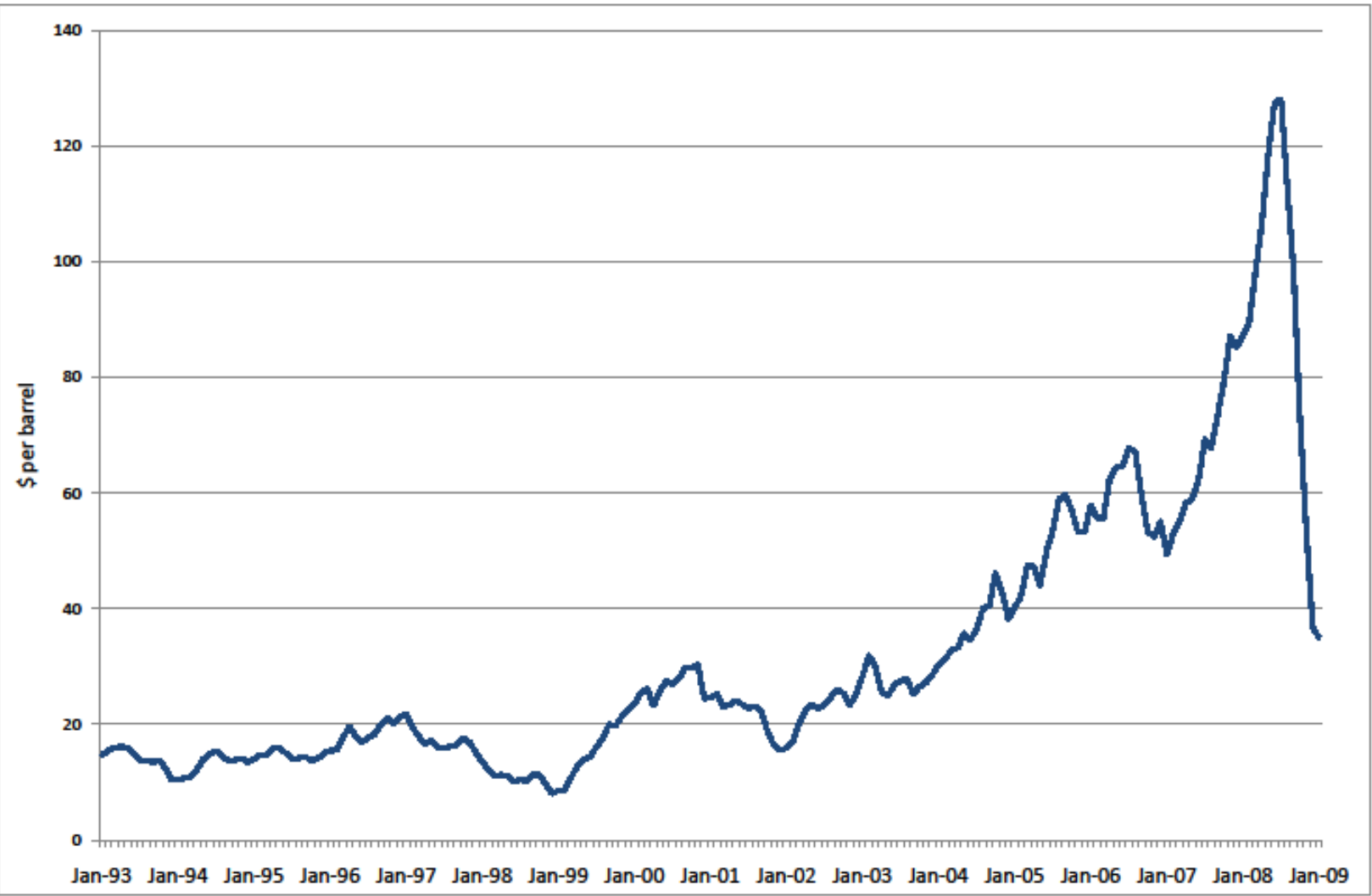




\section{Table 1: Distribution of cases over time and event}

The table shows the distribution of the sample firms over time and event. The CL column reports the number of firms joining the EPA Climate Leaders program in each year, the GHG column reports the number of firms in the Climate Leaders program announcing their goal for greenhouse gas reductions in each year, and the Ceres column reorts the number of firms endorsing the Ceres Principles in each year. Fall of 2008 is defined as announcements taking place in the period September 1 through December 31, 2008.

\begin{tabular}{lcccc}
\hline Announcement year & All sample firms & CL & GHG & Ceres \\
\hline 1993 & 2 & 0 & 0 & 2 \\
1994 & 1 & 0 & 0 & 1 \\
1997 & 3 & 0 & 0 & 1 \\
1998 & 1 & 0 & 0 & 1 \\
1999 & 1 & 0 & 0 & 1 \\
2000 & 1 & 0 & 0 & 1 \\
2001 & 1 & 0 & 0 & 0 \\
2002 & 14 & 13 & 5 & 0 \\
2003 & 12 & 7 & 5 & 1 \\
2004 & 9 & 4 & 4 & 6 \\
2005 & 5 & 0 & 3 & 3 \\
2006 & 22 & 13 & 2 & 0 \\
2007 & 21 & 16 & 3 & 0 \\
2008 & 24 & 21 & 3 & 20 \\
\hline of which in the fall of 2008 & 13 & 10 & 23 & \\
\hline Total & 117 & 74 & & 5 \\
\hline
\end{tabular}




\section{Table 2: Financial and industry characteristics of the sample firms}

The table shows various financial and industry characteristics of the sample firms. The CL column reports summary statistics for the 74 firms that joined the EPA Climate Leaders program, the GHG column reports summary statistics for the 23 Climate Leaders firms that announced a greenhouse gas reduction goal, and the Ceres column reports summary statistics for the 20 firms that endorsed the Ceres Principles, 1993-2008. Market value of equity is measured six trading days prior to the announcement and is obtained from CRSP. Industry rivals are all firms in CRSP with the same 4-digit SIC code as the sample firm in the announcement year. Total sales is measured in the year prior to the announcement and obtained from Compustat. The Herfindahl index is defined as $\sum_{j=1}^{n}\left(s_{j} / \sum_{j=1}^{n} s_{j}\right)^{2}$, where $s_{j}$ is total sales for firm $j$ and $j=[1, n]$ is an index of all firms in the industry. ${ }^{* * *}$, ${ }^{* *}$, and ${ }^{*}$ indicate that the sample firms are significantly different from their respective industry median at the $1 \%, 5 \%$, and $10 \%$ level, respectively, using a two-tailed Wilcoxon rank-sum test.

\begin{tabular}{|c|c|c|c|c|}
\hline & $\begin{array}{l}\text { All sample } \\
\text { firms }\end{array}$ & CL & GHG & Ceres \\
\hline Number of firms & 117 & 74 & 23 & 20 \\
\hline \multicolumn{5}{|l|}{ Market value of equity (MVE, $\$$ billions) } \\
\hline Mean MVE & 77.8 & 93.0 & 86.1 & 12.7 \\
\hline Median MVE & 19.2 & 27.5 & 19.0 & 2.9 \\
\hline Fraction of firms with MVE > industry median MVE & $0.91^{* *}$ & $0.96^{* * *}$ & $0.95^{*}$ & 0.65 \\
\hline \multicolumn{5}{|l|}{ Total sales ( $\$$ billions) } \\
\hline$\overline{\text { Mean sales }}$ & 18.9 & 20.6 & 22.2 & 8.6 \\
\hline Median sales & 9.9 & 9.9 & 14.5 & 8.1 \\
\hline Fraction of sample firms with sales $>$ industry median sales & $0.94^{* * *}$ & $0.99^{* * *}$ & $1.00^{* * *}$ & $0.72^{*}$ \\
\hline \multicolumn{5}{|l|}{ Market-to-book (MB) ratio } \\
\hline$\overline{\text { Mean MB }}$ & 3.68 & 3.73 & 4.11 & 3.01 \\
\hline Median MB & 2.57 & 2.76 & 2.81 & 2.17 \\
\hline Proportion sample firms with MB > industry median MB & $0.63^{* *}$ & $0.63^{* *}$ & $0.77^{*}$ & 0.47 \\
\hline Fraction of sample firms listed on NASDAQ (v. NYSE/Amex) & 0.15 & 0.15 & 0.14 & 0.17 \\
\hline \multicolumn{5}{|l|}{ Number of rival firms in each industry portfolio } \\
\hline Mean \# of rivals & 35 & 31 & 43 & 38 \\
\hline Median \# of rivals & 16 & 12 & 31 & 22 \\
\hline \multicolumn{5}{|l|}{$\underline{\text { Herfindahl industry }(\mathrm{HI}) \text { concentration index }}$} \\
\hline$\overline{\text { Mean HI }}$ & 0.34 & 0.37 & 0.25 & 0.33 \\
\hline Median HI & 0.26 & 0.32 & 0.11 & 0.24 \\
\hline \multicolumn{5}{|l|}{ Fraction of sample firms in the industry of } \\
\hline Manufacturing & 0.57 & 0.59 & 0.61 & 0.45 \\
\hline Finance & 0.09 & 0.08 & 0.09 & 0.15 \\
\hline Transportation & 0.16 & 0.12 & 0.22 & 0.25 \\
\hline Other & 0.18 & 0.21 & 0.08 & 0.15 \\
\hline
\end{tabular}




\section{Table 3: Environmental performance and corporate governance characteristics of the sample firms}

The table shows environmental performance and corporate governance characteristics of the sample firms. The CL column reports summary statistics for the 74 firms that joined the EPA Climate Leaders program, the GHG column reports summary statistics for the 23 Climate Leaders firms that announced a greenhouse gas reduction goal, and the Ceres column reports summary statistics for the 20 firms that endorsed the Ceres Principles, 1993-2008. The criteria for carbon intensity and the emissions of greenhouse gases are taken from the Carbon Disclosure Project and the values are obtained from the firm's sustainability report. The environmental rankings are obtained from KLD Stats in the year prior to the announcement. The GIM index and shareholder proposals are obtained from RiskMetrics. ${ }^{* * *}$, ${ }^{* *}$, and ${ }^{*}$ indicate that the sample firms ratings are significantly different from their respective industry mean at the $1 \%, 5 \%$, and $10 \%$ level, respectively, using a two-tailed Wilcoxon rank-sum test.

\begin{tabular}{|c|c|c|c|c|}
\hline & $\begin{array}{l}\text { All sample } \\
\text { firms }\end{array}$ & CL & GHG & Ceres \\
\hline Number of firms & 117 & 74 & 23 & 20 \\
\hline \multicolumn{5}{|l|}{ Carbon intensity } \\
\hline Fraction of firms in carbon intensive industries & 0.53 & 0.53 & 0.61 & 0.45 \\
\hline \multicolumn{5}{|l|}{ State of incorporation } \\
\hline Fraction of firms in RGGI states & 0.60 & 0.62 & 0.57 & 0.55 \\
\hline Fraction of firms in WCI states & 0.03 & 0.01 & 0.00 & 0.10 \\
\hline \multicolumn{5}{|l|}{ Goal for the reduction of greenhouse gas emissions } \\
\hline Number of firms with greenhouse gas reduction goals & 42 & 19 & 23 & $\mathrm{n} / \mathrm{a}$ \\
\hline Mean reduction goal & $16 \%$ & $17 \%$ & $16 \%$ & $\mathrm{n} / \mathrm{a}$ \\
\hline Median reduction goal & $15 \%$ & $15 \%$ & $15 \%$ & $\mathrm{n} / \mathrm{a}$ \\
\hline Mean \# of years to achieve goal & 6.8 & 6.7 & 6.8 & $\mathrm{n} / \mathrm{a}$ \\
\hline Median \# of years to achieve goal & 6.0 & 6.0 & 6.0 & $\mathrm{n} / \mathrm{a}$ \\
\hline Number of sample firms with KLD data & 99 & 64 & 21 & 14 \\
\hline \multicolumn{5}{|l|}{ Environmental strengths } \\
\hline Mean \# of strengths & $0.47^{* * *}$ & $0.39^{* *}$ & $0.67^{* * *}$ & $0.57^{* *}$ \\
\hline Proportion firms with score $\geq$ industry mean & 0.75 & 0.72 & 0.77 & 0.87 \\
\hline \multicolumn{5}{|l|}{ Environmental concerns } \\
\hline Mean \# of concerns & $0.79^{* * *}$ & $0.81^{* *}$ & 0.95 & 0.43 \\
\hline Proportion firms with score $\geq$ industry mean & 0.77 & 0.76 & 0.73 & 0.87 \\
\hline \multicolumn{5}{|l|}{ GIM corporate governance index (max 18 ) } \\
\hline Number of firms with GIM index score & 96 & 60 & 21 & 15 \\
\hline Mean GIM index & 9.5 & 9.7 & 9.1 & 9.0 \\
\hline Median GIM index & 9.0 & 10.0 & 9.0 & 9.0 \\
\hline \multicolumn{5}{|l|}{ \# of shareholder proposals related to climate change } \\
\hline Number of firms with at least one shareholder proposal & 10 & 7 & 3 & 0 \\
\hline Mean \# of proposals & 0.12 & 0.14 & 0.17 & 0 \\
\hline Median \# of proposals & 0 & 0 & 0 & 0 \\
\hline
\end{tabular}




\section{Table 4: Announcement cumulative abnormal return $(\overline{C A R})$ estimates for the sample firms}

The CL columns report results for firms that joined the EPA Climate Leaders program, the GHG columns report results for the Climate Leaders firms that announced a greenhouse gas reduction goal, and the Ceres columns report results for the firms that endorsed the Ceres Principles, 1993-2008. The abnormal return for firm $j$ is estimated as $\widehat{A R}_{j t}=$ $R_{j t}-\left(\hat{\alpha}_{j}+\hat{\beta}_{j} R_{m t}\right)$, where $R_{j t}$ is the return of the stock of firm $j$ on day $t ; R_{m t}$ is the equal-weighted market return on day $t$; and $\hat{\alpha}_{j}$ and $\hat{\beta}_{j}$ are the coefficients estimated from the single-factor market model $R_{j t}=\alpha_{j}+\beta_{j} R_{m t}+\epsilon_{j t}$ over 250 days, ending on day -3 . The standardized cross-sectional test is an extension of the Patell (1996) test introduced by Boehmer, Musimeci and Poulsen (1991). The ratio of positive to negative $\widehat{C A R}$ s is tested with a generalized sign test (Cowan, 1992). ${ }^{* * *},{ }^{* *}$ and ${ }^{*}$ denotes significance for a 2-tailed test at the $1 \%, 5 \%$, and $10 \%$ level, respectively.

\begin{tabular}{|c|c|c|c|c|c|c|c|}
\hline Column number & 1 & 2 & 3 & 4 & 5 & 6 & 7 \\
\hline & \multicolumn{2}{|c|}{ All sample firms } & \multicolumn{3}{|c|}{ CL } & GHG & Ceres \\
\hline Includes announcements in fall 2008 & $\begin{array}{c}1993-2008 \\
\text { yes }\end{array}$ & $\begin{array}{c}1993-2008 \\
\text { no }\end{array}$ & $\begin{array}{c}\text { 2002-2008 } \\
\text { no }\end{array}$ & 2002-2005 & $\begin{array}{c}2006-2008 \\
\text { no }\end{array}$ & $\begin{array}{c}2002-2008 \\
\text { no }\end{array}$ & $\begin{array}{c}1993-2008 \\
\text { no }\end{array}$ \\
\hline \multicolumn{8}{|l|}{ Panel A. Event window $[0,1]$} \\
\hline Average $\widehat{C A R}_{0,1}$ (in \%) & -0.03 & -0.54 & -0.59 & -0.47 & -0.67 & -1.01 & 0.11 \\
\hline Standardized cross-sectional test Z & -1.050 & $-3.101^{* * *}$ & $-1.994^{* *}$ & -0.743 & $-1.965^{* *}$ & $-3.439^{* * *}$ & -0.354 \\
\hline Bootstrap Patell Z & -1.282 & $-2.622^{* * *}$ & $-1.790^{*}$ & -0.679 & $-1.751^{*}$ & $-2.504^{* *}$ & -0.262 \\
\hline Ratio of positive to negative $\widehat{C A R}_{0,1}$ & $51: 66$ & $39: 62^{* *}$ & $24: 37$ & $12: 12$ & $12: 25^{* *}$ & $6: 14^{*}$ & 9:11 \\
\hline Number of observations & 117 & 101 & 61 & 24 & 37 & 20 & 20 \\
\hline \multicolumn{8}{|l|}{ Panel B. Event window $[-1,1]$} \\
\hline Average $\widehat{C A R}_{-1,1}$ (in \%) & -0.20 & -0.73 & -1.00 & -0.73 & -1.17 & -1.13 & 0.45 \\
\hline Standardized cross-sectional test Z & -1.471 & $-3.603^{* * *}$ & $-3.398^{* * *}$ & -1.369 & $-3.300^{* * *}$ & $-2.750^{* * *}$ & 0.493 \\
\hline Bootstrap Patell Z & -1.608 & $-2.757^{* * *}$ & $-2.547^{* *}$ & -1.103 & $-2.731^{* * *}$ & $-2.171^{* *}$ & 0.344 \\
\hline Ratio of positive to negative $\widehat{C A R}_{-1,1}$ & $44: 65^{*}$ & $35: 58^{* *}$ & $19: 39^{* *}$ & $8: 14$ & $11: 25^{* *}$ & $4: 12^{*}$ & $12: 7$ \\
\hline Number of observations & 109 & 93 & 58 & 22 & 36 & 16 & 19 \\
\hline \multicolumn{8}{|l|}{ Panel C. Event window [-2,2] } \\
\hline Average $\overline{C A R}_{-2,2}$ (in \%) & -0.44 & -1.08 & -1.50 & -1.83 & -1.28 & -1.16 & 0.33 \\
\hline Standardized cross-sectional test Z & -1.590 & $-3.034^{* * *}$ & $-2.997^{* * *}$ & $-1.700^{*}$ & $-2.438^{* *}$ & -1.547 & 0.419 \\
\hline Bootstrap Patell Z & $-2.087^{* *}$ & $-3.079^{* * *}$ & $-3.145^{* * *}$ & $-1.743^{*}$ & $-2.639^{* * *}$ & $-1.708^{*}$ & 0.299 \\
\hline Ratio of positive to negative $\widehat{C A R}_{-2,2}$ & $34: 56^{* *}$ & $25: 52^{* * *}$ & $15: 32^{* *}$ & $6: 13$ & $9: 19^{*}$ & $3: 12^{* *}$ & $7: 8$ \\
\hline Number of observations & 90 & 77 & 47 & 19 & 28 & 15 & 15 \\
\hline
\end{tabular}




\section{Table 5: Cross-sectional determinants of the announcement $\widehat{C A R} \mathrm{~s}$}

Coefficient estimates from WLS regressions of the announcement cumulative abnormal returns over the [-1,1] window, $\widehat{C A R}_{j,-1,1}$. The weight is the standard deviation of the residual in the market model estimation. The sample comprises of 70 firms that joined the EPA Climate Leaders program (CL) or pledged a greenhouse gas goal (GHG), 1/2002-8/2008. . p-values are in parenthesis.

\begin{tabular}{|c|c|c|c|c|c|c|}
\hline Intercept & $\begin{array}{c}-0.030 \\
(0.160)\end{array}$ & $\begin{array}{c}-0.054 \\
(0.068)\end{array}$ & $\begin{array}{c}-0.020 \\
(0.349)\end{array}$ & $\begin{array}{c}-0.037 \\
(0.277)\end{array}$ & $\begin{array}{c}-0.013 \\
(0.629)\end{array}$ & $\begin{array}{c}-0.041 \\
(0.381)\end{array}$ \\
\hline Ln (Climate press hits) & $\begin{array}{c}0.005 \\
(0.065)\end{array}$ & $\begin{array}{c}0.009 \\
(0.041)\end{array}$ & $\begin{array}{c}0.007 \\
(0.014)\end{array}$ & $\begin{array}{c}0.009 \\
(0.059)\end{array}$ & $\begin{array}{c}0.005 \\
(0.085)\end{array}$ & $\begin{array}{c}0.009 \\
(0.140)\end{array}$ \\
\hline Crude oil price residual & $\begin{array}{c}0.000 \\
(0.069)\end{array}$ & $\begin{array}{c}0.000 \\
(0.063)\end{array}$ & $\begin{array}{c}0.000 \\
(0.194)\end{array}$ & $\begin{array}{c}0.000 \\
(0.187)\end{array}$ & $\begin{array}{c}0.000 \\
(0.322)\end{array}$ & $\begin{array}{c}0.000 \\
(0.295)\end{array}$ \\
\hline Carbon intensive industry & $\begin{array}{c}-0.008 \\
(0.127)\end{array}$ & $\begin{array}{c}-0.009 \\
(0.076)\end{array}$ & $\begin{array}{c}0.000 \\
(0.978)\end{array}$ & $\begin{array}{c}0.000 \\
(0.978)\end{array}$ & $\begin{array}{c}0.006 \\
(0.485)\end{array}$ & $\begin{array}{c}0.007 \\
(0.401)\end{array}$ \\
\hline Market value of equity (\$ bill.) & $\begin{array}{c}-0.047 \\
(0.018)\end{array}$ & $\begin{array}{c}-0.047 \\
(0.017)\end{array}$ & $\begin{array}{c}-0.071 \\
(0.001)\end{array}$ & $\begin{array}{c}-0.072 \\
(0.001)\end{array}$ & $\begin{array}{c}-0.036 \\
(0.205)\end{array}$ & $\begin{array}{c}-0.038 \\
(0.185)\end{array}$ \\
\hline Market-to-book ratio & $\begin{array}{c}-0.001 \\
(0.050)\end{array}$ & $\begin{array}{c}-0.001 \\
(0.035)\end{array}$ & $\begin{array}{c}-0.001 \\
(0.063)\end{array}$ & $\begin{array}{c}-0.001 \\
(0.068)\end{array}$ & $\begin{array}{c}-0.003 \\
(0.023)\end{array}$ & $\begin{array}{c}-0.003 \\
(0.023)\end{array}$ \\
\hline Herfindahl index & $\begin{array}{c}-0.006 \\
(0.459)\end{array}$ & $\begin{array}{c}-0.006 \\
(0.450)\end{array}$ & $\begin{array}{c}-0.003 \\
(0.736)\end{array}$ & $\begin{array}{c}-0.003 \\
(0.747)\end{array}$ & $\begin{array}{c}-0.002 \\
(0.826)\end{array}$ & $\begin{array}{c}-0.001 \\
(0.893)\end{array}$ \\
\hline RGGI state & $\begin{array}{c}-0.006 \\
(0.198)\end{array}$ & $\begin{array}{c}-0.005 \\
(0.281)\end{array}$ & $\begin{array}{c}-0.010 \\
(0.028)\end{array}$ & $\begin{array}{c}-0.009 \\
(0.040)\end{array}$ & $\begin{array}{c}-0.006 \\
(0.356)\end{array}$ & $\begin{array}{c}-0.005 \\
(0.415)\end{array}$ \\
\hline Shareholder climate proposals & & & & & $\begin{array}{c}0.000 \\
(0.965)\end{array}$ & $\begin{array}{c}0.000 \\
(0.928)\end{array}$ \\
\hline KLD environmental strengths & & & & & $\begin{array}{c}-0.002 \\
(0.722)\end{array}$ & $\begin{array}{c}0.000 \\
(0.841)\end{array}$ \\
\hline KLD environmental concerns & & & & & $\begin{array}{c}0.000 \\
(0.709)\end{array}$ & $\begin{array}{c}-0.001 \\
(0.678)\end{array}$ \\
\hline GIM index & & & $\begin{array}{c}-0.003 \\
(0.006)\end{array}$ & $\begin{array}{c}-0.003 \\
(0.007)\end{array}$ & $\begin{array}{c}-0.002 \\
(0.032)\end{array}$ & $\begin{array}{c}-0.002 \\
(0.030)\end{array}$ \\
\hline KLD corp. governance strengths & & & & & $\begin{array}{c}0.001 \\
(0.980)\end{array}$ & $\begin{array}{c}0.004 \\
(0.884)\end{array}$ \\
\hline KLD corp. governance concerns & & & & & $\begin{array}{c}-0.004 \\
(0.437)\end{array}$ & $\begin{array}{c}-0.003 \\
(0.654)\end{array}$ \\
\hline Board stock ownership fraction & & & & & $\begin{array}{c}0.001 \\
(0.124)\end{array}$ & $\begin{array}{c}0.001 \\
(0.109)\end{array}$ \\
\hline Time dummy 2006-2008 & & $\begin{array}{c}-0.010 \\
(0.237)\end{array}$ & & $\begin{array}{c}-0.006 \\
(0.522)\end{array}$ & & $\begin{array}{c}-0.009 \\
(0.462)\end{array}$ \\
\hline Number of cases, $\mathrm{N}$ & 70 & 70 & 61 & 61 & 57 & 57 \\
\hline Adjusted $\mathrm{R}^{2}$ & 0.147 & 0.152 & 0.290 & 0.282 & 0.178 & 0.169 \\
\hline F-value & $\begin{array}{c}2.72 \\
(0.016)\end{array}$ & $\begin{array}{c}2.57 \\
(0.017)\end{array}$ & $\begin{array}{c}4.12 \\
(0.001)\end{array}$ & $\begin{array}{c}3.66 \\
(0.001)\end{array}$ & $\begin{array}{c}1.88 \\
(0.057)\end{array}$ & $\begin{array}{c}1.77 \\
(0.073)\end{array}$ \\
\hline
\end{tabular}

\footnotetext{
${ }^{\mathrm{a}}$ The number of cases $\mathrm{N}$ is less than 74 due to missing explanatory variables in 4 cases.
} 


\section{Table 6: Announcement cumulative abnormal return $(\widehat{C A R})$ estimates for rival firm portfolios}

The CL columns report results for the rivals of firms that joined the EPA Climate Leaders program, the GHG columns report results for the rivals of Climate Leaders firms that announced a greenhouse gas reduction goal, and the Ceres columns report results for the rivals of firms that endorsed the Ceres Principles, 1993-2008. The abnormal return for portfolio $r$ is estimated as $\widehat{A R}_{r t}=R_{r t}-\left(\hat{\alpha}_{r}+\hat{\beta}_{r} R_{m t}\right)$, where $R_{r t}$ is the return of an equal-weighted portfolio $r$ of the sample firm's industry rivals on day $t$; $R_{m t}$ is the equalweighted market return on day $t$; and $\hat{\alpha}_{r}$ and $\hat{\beta}_{r}$ are the coefficients estimated from the market model $R_{r t}=\alpha_{r}+\beta_{r} R_{m t}+\epsilon_{r t}$ over 250 days, ending on day -3. The standardized cross-sectional test is an extension of the Patell (1996) test introduced by Boehmer, Musimeci and Poulsen (1991). The ratio of positive to negative CARs is tested with a generalized sign test (Cowan, 1992). ${ }^{* * *}, * *$ and ${ }^{*}$ denotes significance for a 2 -tailed test at the $1 \%, 5 \%$, and $10 \%$ level, respectively.

\begin{tabular}{|c|c|c|c|c|c|c|c|}
\hline Column number & 1 & 2 & 3 & 4 & 5 & 6 & 7 \\
\hline & \multicolumn{2}{|c|}{ All sample firms } & \multicolumn{3}{|c|}{ CL } & GHG & Ceres \\
\hline Includes announcements in fall 2008 & $\begin{array}{c}\text { 1993-2008 } \\
\text { yes }\end{array}$ & $\begin{array}{c}1993-2008 \\
\text { no }\end{array}$ & $\begin{array}{c}2002-2008 \\
\text { no }\end{array}$ & $2002-2005$ & $\begin{array}{c}\text { 2006-2008 } \\
\text { no }\end{array}$ & $\begin{array}{c}\text { 2002-2008 } \\
\text { no }\end{array}$ & $\begin{array}{c}1993-2008 \\
\text { no }\end{array}$ \\
\hline \multicolumn{8}{|l|}{ Panel A. Event window [0,1] } \\
\hline Average $\widehat{C A R}_{0,1}$ (in \%) & 0.16 & 0.00 & 0.08 & -0.02 & 0.15 & -0.23 & 0.00 \\
\hline Standardized cross-sectional test Z & 0.849 & -0.277 & 0.616 & 0.403 & 0.459 & -0.766 & -0.443 \\
\hline Bootstrap Patell Z & 1.059 & -0.287 & 0.559 & 0.355 & 0.432 & -0.972 & -0.461 \\
\hline Ratio of positive to negative $\widehat{C A R}_{0,1}$ & $55: 53$ & $46: 48$ & $28: 28$ & $11: 13$ & $17: 15$ & $8: 11$ & $10: 9$ \\
\hline Number of rival firm portfolios & 108 & 94 & 56 & 24 & 32 & 19 & 19 \\
\hline \multicolumn{8}{|l|}{ Panel B. Event window $[-1,1]$} \\
\hline Average $\widehat{C A R}_{-1,1}$ (in \%) & 0.22 & -0.08 & 0.05 & 0.19 & -0.05 & -0.52 & -0.08 \\
\hline Standardized cross-sectional test Z & 0.166 & -0.995 & -0.301 & 0.603 & -0.627 & -1.589 & -0.514 \\
\hline Bootstrap Patell Z & 0.222 & -1.157 & -0.390 & 0.530 & -0.957 & -1.540 & -0.454 \\
\hline Ratio of positive to negative $\widehat{C A R}_{-1,1}$ & $44: 56$ & $35: 51^{*}$ & 23:30 & $10: 12$ & $13: 18$ & $2: 13^{* * *}$ & $10: 8$ \\
\hline Number of rival firm portfolios & 100 & 86 & 53 & 22 & 31 & 15 & 18 \\
\hline \multicolumn{8}{|l|}{ Panel C. Event window [-2,2] } \\
\hline Average $\widehat{C A R}_{-2,2}$ (in \%) & 0.21 & -0.07 & 0.10 & 1.46 & -0.98 & -0.95 & 0.31 \\
\hline Standardized cross-sectional test Z & 0.107 & -0.758 & -0.330 & $1.801^{*}$ & $-1.661^{*}$ & $-1.840^{*}$ & 0.927 \\
\hline Bootstrap Patell Z & 0.167 & -0.840 & -0.223 & $1.836^{*}$ & $-2.191^{* *}$ & $-1.736^{*}$ & 0.573 \\
\hline Ratio of positive to negative $\widehat{C A R}_{-2,2}$ & $38: 44$ & $31: 40$ & $21: 22$ & 13:6 & 8:16 & $3: 11^{* *}$ & $7: 7$ \\
\hline Number of rival firm portfolios & 82 & 71 & 43 & 19 & 24 & 14 & 14 \\
\hline
\end{tabular}


Table 7: Determinants of the decision to join Climate Leaders

Coefficient estimates from probit regressions for the probability that a firm joins Climate Leaders (CL) in 20022008. The sample is 78 firms in CL and 1,237 of unique industry-year rivals. p-values are in parenthesis.

\begin{tabular}{|c|c|c|c|c|c|c|}
\hline Intercept & $\begin{array}{c}-4.459 \\
(0.000)\end{array}$ & $\begin{array}{c}18.04 \\
(0.000)\end{array}$ & $\begin{array}{c}-6.704 \\
(0.000)\end{array}$ & $\begin{array}{c}14.35 \\
(0.002)\end{array}$ & $\begin{array}{c}-6.102 \\
(0.000)\end{array}$ & $\begin{array}{c}13.99 \\
(0.005)\end{array}$ \\
\hline Ln (Climate press hits) & $\begin{array}{c}0.293 \\
(0.065)\end{array}$ & $\begin{array}{c}-3.139 \\
(0.000)\end{array}$ & $\begin{array}{c}0.539 \\
(0.004)\end{array}$ & $\begin{array}{c}-2.701 \\
(0.000)\end{array}$ & $\begin{array}{c}0.445 \\
(0.030)\end{array}$ & $\begin{array}{l}-2.633 \\
(0.000)\end{array}$ \\
\hline Crude oil price residual & $\begin{array}{c}-0.014 \\
(0.093)\end{array}$ & $\begin{array}{c}0.016 \\
(0.131)\end{array}$ & $\begin{array}{c}-0.021 \\
(0.036)\end{array}$ & $\begin{array}{c}0.003 \\
(0.808)\end{array}$ & $\begin{array}{c}-0.024 \\
(0.028)\end{array}$ & $\begin{array}{c}-0.003 \\
(0.778)\end{array}$ \\
\hline Carbon intensive industry & $\begin{array}{c}-0.319 \\
(0.212)\end{array}$ & $\begin{array}{c}-0.333 \\
(0.227)\end{array}$ & $\begin{array}{c}-0.531 \\
(0.083)\end{array}$ & $\begin{array}{c}-0.555 \\
(0.096)\end{array}$ & $\begin{array}{c}-0.530 \\
(0.148)\end{array}$ & $\begin{array}{c}-0.541 \\
(0.163)\end{array}$ \\
\hline Market value of equity ( $\$$ bill.) & $\begin{array}{c}-0.740 \\
(0.055)\end{array}$ & $\begin{array}{c}-1.078 \\
(0.016)\end{array}$ & $\begin{array}{c}-1.118 \\
(0.017)\end{array}$ & $\begin{array}{c}-1.523 \\
(0.002)\end{array}$ & $\begin{array}{l}-1.619 \\
(0.016)\end{array}$ & $\begin{array}{l}-2.008 \\
(0.003)\end{array}$ \\
\hline Market-to-book ratio & $\begin{array}{c}0.000 \\
(0.939)\end{array}$ & $\begin{array}{c}0.000 \\
(0.954)\end{array}$ & $\begin{array}{c}0.031 \\
(0.211)\end{array}$ & $\begin{array}{c}0.043 \\
(0.086)\end{array}$ & $\begin{array}{c}0.015 \\
(0.560)\end{array}$ & $\begin{array}{c}0.025 \\
(0.369)\end{array}$ \\
\hline NASDAQ & $\begin{array}{c}-2.395 \\
(0.000)\end{array}$ & $\begin{array}{c}-2.358 \\
(0.000)\end{array}$ & $\begin{array}{c}-1.452 \\
(0.001)\end{array}$ & $\begin{array}{c}-1.309 \\
(0.003)\end{array}$ & $\begin{array}{l}-1.177 \\
(0.015)\end{array}$ & $\begin{array}{l}-1.804 \\
(0.028)\end{array}$ \\
\hline RGGI state & $\begin{array}{c}0.637 \\
(0.014)\end{array}$ & $\begin{array}{c}0.610 \\
(0.025)\end{array}$ & $\begin{array}{c}0.324 \\
(0.295)\end{array}$ & $\begin{array}{c}0.302 \\
(0.353)\end{array}$ & $\begin{array}{c}0.147 \\
(0.672)\end{array}$ & $\begin{array}{c}0.040 \\
(0.913)\end{array}$ \\
\hline Shareholder climate proposals & $\begin{array}{c}0.861 \\
(0.007)\end{array}$ & $\begin{array}{c}1.389 \\
(0.010)\end{array}$ & $\begin{array}{c}0.884 \\
(0.009)\end{array}$ & $\begin{array}{c}1.031 \\
(0.003)\end{array}$ & $\begin{array}{c}0.806 \\
(0.031)\end{array}$ & $\begin{array}{c}1.000 \\
(0.007)\end{array}$ \\
\hline KLD environmental strengths & & & & & $\begin{array}{c}0.593 \\
(0.016)\end{array}$ & $\begin{array}{c}0.471 \\
(0.069)\end{array}$ \\
\hline KLD environmental concerns & & & & & $\begin{array}{c}-0.128 \\
(0.406)\end{array}$ & $\begin{array}{c}-0.155 \\
(0.339)\end{array}$ \\
\hline GIM index & & & $\begin{array}{c}0.101 \\
(0.082)\end{array}$ & $\begin{array}{c}0.113 \\
(0.065)\end{array}$ & $\begin{array}{c}0.116 \\
(0.075)\end{array}$ & $\begin{array}{c}0.121 \\
(0.071)\end{array}$ \\
\hline KLD corp. governance strengths & & & & & $\begin{array}{c}-0.759 \\
(0.486)\end{array}$ & $\begin{array}{l}-0.944 \\
(0.417)\end{array}$ \\
\hline KLD corp. governance concerns & & & & & $\begin{array}{c}0.389 \\
(0.168)\end{array}$ & $\begin{array}{c}0.540 \\
(0.084)\end{array}$ \\
\hline Board stock ownership fraction & & & & & $\begin{array}{c}0.008 \\
(0.678)\end{array}$ & $\begin{array}{c}0.005 \\
(0.825)\end{array}$ \\
\hline Time dummy 2006-2008 & & $\begin{array}{c}7.627 \\
(0.000)\end{array}$ & & $\begin{array}{c}7.360 \\
(0.000)\end{array}$ & & $\begin{array}{c}7.038 \\
(0.000)\end{array}$ \\
\hline $\begin{array}{l}\text { Number of sample firms } \\
\text { Number of rival firms }\end{array}$ & $\begin{array}{c}78 \\
1,237\end{array}$ & $\begin{array}{c}78 \\
1,237\end{array}$ & $\begin{array}{c}65 \\
465\end{array}$ & $\begin{array}{c}65 \\
465\end{array}$ & $\begin{array}{c}61 \\
356\end{array}$ & $\begin{array}{c}61 \\
356\end{array}$ \\
\hline Nagelkerke $\mathrm{R}^{2}$ & 0.162 & 0.249 & 0.139 & 0.244 & 0.176 & 0.267 \\
\hline$\chi^{2}$ & $\begin{array}{c}79.57 \\
(0.000)\end{array}$ & $\begin{array}{l}124.6 \\
(0.000)\end{array}$ & $\begin{array}{c}40.25 \\
(0.000)\end{array}$ & $\begin{array}{c}72.64 \\
(0.000)\end{array}$ & $\begin{array}{c}43.75 \\
(0.000)\end{array}$ & $\begin{array}{c}68.22 \\
(0.000)\end{array}$ \\
\hline
\end{tabular}

